\title{
1 Title: The prevalence and impact of transient species in ecological communities
}

2

3

4

5

6

727599

$8 \quad 2$ Migratory Bird Center, Smithsonian Conservation Biology Institute, Washington, DC, 20013

$9{ }^{3}$ Department of Wildlife Ecology and Conservation, 110 Newins-Ziegler Hall, PO Box 110430,

10 University of Florida, Gainesville, FL 32611-0430, USA

$11{ }^{4}$ Informatics Institute, 432 Newell Drive, PO Box 115585, University of Florida, Gainesville, FL

$12 \quad 32611-8545$

$13{ }^{5}$ Curriculum for the Environment and Ecology, University of North Carolina, Chapel Hill, North

14 Carolina 27599

15

16

17

18

19

20

21

22

23

24

25

26

27

28

29

30

31

32

33

34

35

36

37

38 *corresponding author; email: hurlbert @ bio.unc.edu

Running head: $\quad$ Transient species: prevalence and impact

keywords: occupancy, spatial scale, species-area, species abundance distribution, transient species

Manuscript type: Article

Total number of words (Introduction through Discussion): 5068

Manuscript elements:

5 Figures

1 Table

Appendix

* Table A1

* Figures A1-A6 
39 Abstract

41 local populations. Because transient species interact differently than non-transients with their

42 biotic and abiotic environment, it is important to characterize the prevalence of these species and

43 how they impact our understanding of ecological systems. We quantified the prevalence and

44 impact of transient species in communities using data on over 17,000 community time series

45 spanning an array of ecosystems, taxonomic groups, and spatial scales. We found that transient

46 species are a general feature of communities regardless of taxa or ecosystem. The proportion of

47 these species decreases with spatial scale leading to a need to control for scale in comparative

48 work. Removing transient species from analyses influences the form of a suite of commonly

49 studied ecological patterns including species-abundance distributions, species-energy

50 relationships, species-area relationships, and temporal turnover. Careful consideration should be

51 given to whether transient species are included in analyses depending on the theoretical and

52 practical relevance of these species for the question being studied.

53

54 


\section{Introduction}

Ecologists frequently conduct taxonomic surveys to characterize the diversity and

57 composition of ecological assemblages. While many of the species observed in these surveys

58 represent local populations, some may be irregular visitors that do not maintain viable local

59 populations, are poorly suited to the local conditions, and rarely interact with other members of

60 the community. Grinnell (1922) first coined the term "accidental" to refer to this kind of species,

61 which is observed inconsistently at a site over time in contrast to the more regular and predictable

62 members of an assemblage. This group of species has also been referred to as "occasional",

63 "vagrant", "transient", and "tourist" (Southwood et al. 1982; Costello and Myers 1996; Novotný

64 and Basset 2000; Magurran and Henderson 2003; Ulrich and Ollik 2004; Dolan et al. 2009; Coyle

65 et al. 2013; Petersen et al. 2015; Supp et al. 2015). Regardless of the name applied, these species

66 (hereafter "transients") have generally been identified based on the low frequency of observations

67 recorded in samples or surveys over time at a given location (i.e., low temporal occupancy).

68 Several studies ranging from birds to fish to amphipods have found that temporal occupancy is

69 frequently bimodally distributed within communities, with one distinct mode at very low

70 occupancy reflecting transient species, and another mode at high occupancy reflecting temporally

71 persistent "core" species (Figure 1A; Costello and Myers 1996; Magurran and Henderson 2003;

72 Coyle et al. 2013; Umaña et al. 2017). The existence of a mode at low occupancy indicates that

73 transient species may make up a larger proportion of ecological assemblages than has typically

74 been acknowledged.

Transient species are expected to interact with their biotic and abiotic environments

76 differently than core species since by definition they do not maintain viable local populations and

77 are not necessarily well adapted to the local environments in which they are found (Magurran and

78 Henderson 2003; Coyle et al. 2013; Umaña et al. 2017). Previous studies found that core 
A

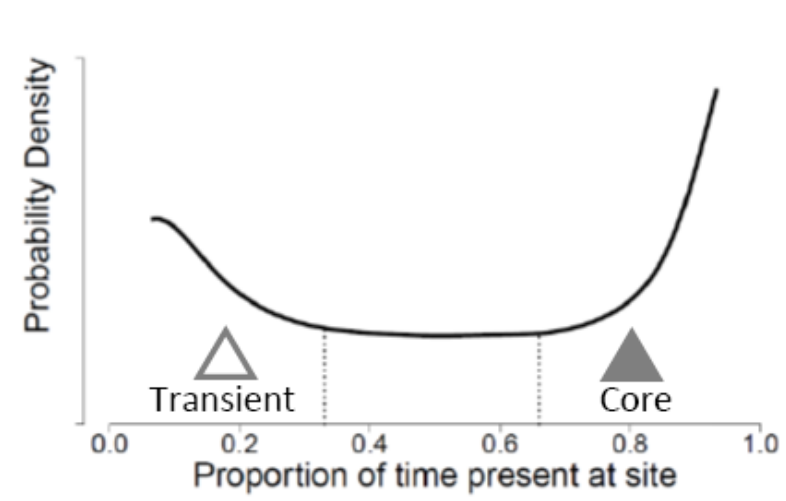

C

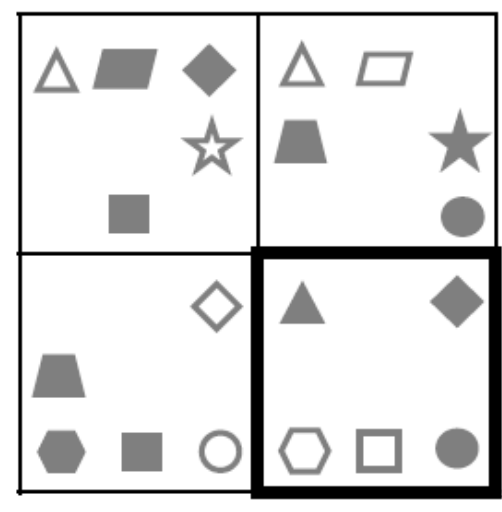

B

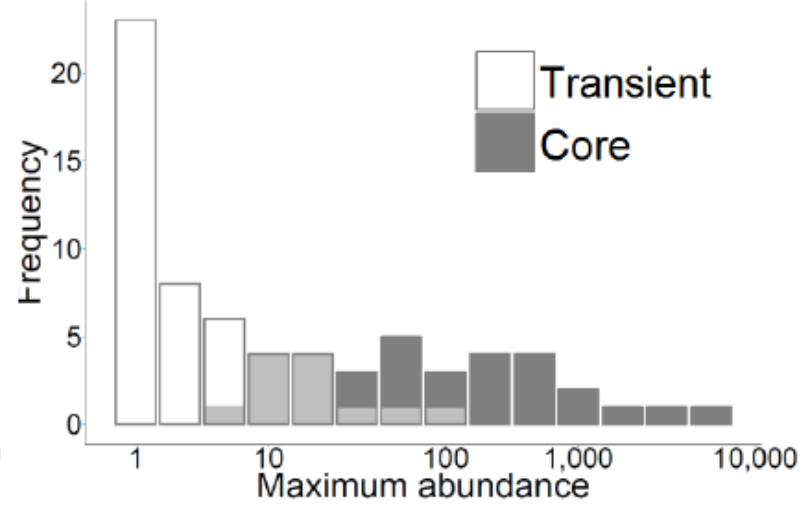

D

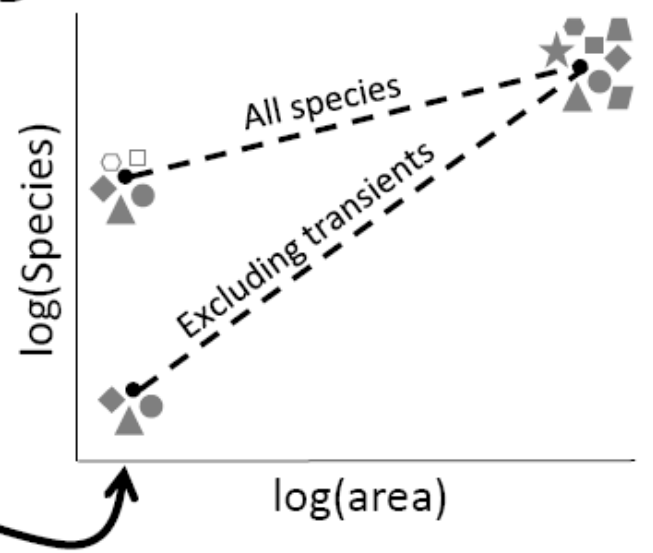

$\mathrm{E}$
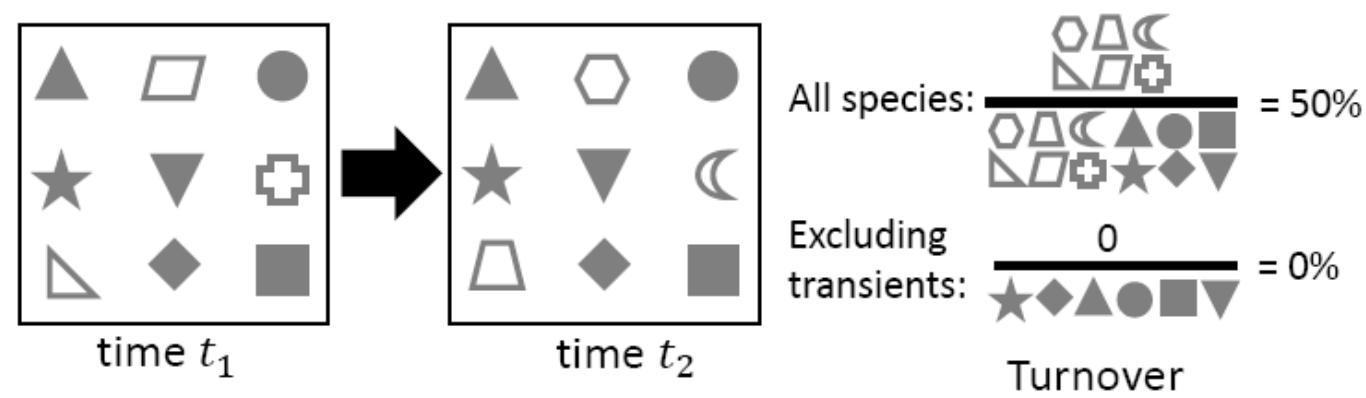

Figure 1. (A) Bimodal distribution of temporal occupancy for North American birds from Coyle et al. (2013) illustrating one mode of "core" species observed consistently at sites and a mode of low occupancy "transient" species observed irregularly. (B) Core and transient species exhibit different species abundance distributions for the Hinkley Point fish assemblage (Magurran and Henderson 2003). (C) Four contiguous quadrats in which species (different shapes) may be core (shaded) or transient (open). (D) The species-area relationships for (C) depending on whether transient species are excluded or not, using the lower right panel to represent the smallest area. Because every species is core in at least one quadrat, species richness at the largest scale is the same for the two relationships. (E) Temporal turnover (the Jaccard index of dissimilarity) is much lower when transient species are excluded from the calculation, since they are the species most driving turnover. 
80 species presence is more strongly tied to the environment and other deterministic factors, while

81 transient presence is more strongly determined by stochastic factors (e.g., Magurran and

82 Henderson 2003; Coyle et al. 2013; Umaña et al. 2017). Because much of the ecological theory

83 related to species coexistence, niche partitioning, and biodiversity assumes that species directly

84 interact and occur only in suitable environments, the presence of these transient species has the

85 potential to skew our understanding of ecological systems. Indeed, transient species have been

86 shown to differ from core species with respect to the shape of species abundance distributions

87 (Figure 1B; Magurran and Henderson 2003), the relative importance of density-dependence versus

88 environmental stochasticity (Magurran and Henderson 2003; Ulrich and Ollik 2004), the primary

89 drivers of species richness (Coyle et al. 2013), and life history traits (Supp et al. 2015). We expect

90 transient species may influence the slope of species-area relationships, since species that are

91 transient may make up a disproportionate fraction of the community at smaller spatial scales, while

92 at large scales most species are expected to maintain persistent populations over at least some

93 subset of the domain (Figures 1C, D). Transient species are also likely to contribute

94 disproportionately to estimates of temporal turnover since by definition they are present in only a

95 small proportion of samples over time (Figure 1E). Thus, a wide variety of classic ecological

96 patterns may differ depending on whether transient species are considered, including biodiversity

97 patterns that have the potential to influence conservation and management decisions.

Given the potential impact of transient species on understanding and managing ecological

99 systems, it is important to understand more about how common transient species are and how their

100 prevalence varies with taxonomic group, ecosystem types, environmental context, and scale. There

101 are reasons to expect that several of these factors may influence the prevalence of transients. First,

102 species from taxonomic groups with strong dispersal abilities like birds commonly show up in 
103 habitats and regions in which they are not expected (Grinnell 1922; Coyle et al. 2013), whereas

104 organisms with limited dispersal should do so much less frequently. Second, assemblages located

105 in regions of high habitat heterogeneity are expected to receive more transient individuals from

106 adjacent habitats via mass effects (Shmida and Wilson 1985). Coyle et al. (2013) found that

107 mountainous regions had a greater proportion of transient bird species, consistent with these

108 predictions. Third, at small scales (e.g., below the average home range size), most organisms will

109 only be observed occasionally and the majority will therefore be classified as transients. At large

110 scales (e.g., an entire continent), nearly all species will maintain viable populations and be

111 consistently observed, and almost none will be classified as transient. Understanding variation in

112 the prevalence of transient species will improve our understanding of the factors structuring

113 communities and help identify study systems where our understanding of ecological systems is

114 most prone to being influenced by their presence. Making comparisons across ecosystems and

115 taxonomic groups will require understanding the scale-dependence of transient species' prevalence

116 because the scale at which assemblages are sampled can vary by several orders of magnitude.

118 transient species in ecological communities. We use data from over 17,000 community time series

119 from terrestrial, aquatic, and marine ecosystems across seven major taxonomic groups to: 1)

120 evaluate the prevalence of transient species and how it varies with taxonomic group, ecosystem

121 type, and habitat heterogeneity; 2) assess the scale-dependence of transient species prevalence and

122 correct for scale to make consistent comparisons across groups; and 3) examine how the inclusion

123 of transient species in community-level analyses impacts four commonly analyzed ecological

124 patterns including the shape of species-abundance distributions, drivers of species richness,

125 species-area relationships, and temporal turnover. 


\section{Methods}

\section{Data}

We conducted an extensive search for datasets of community composition over time both

129 online and published in the literature. We identified datasets using a combination of existing

130 compilations (Dornelas et al. 2014; Yenni et al. 2016), searching online data catalogs such as the

131 Ecological Data Wiki (ecologicaldata.org, White 2016), exploring datasets available from Long-

132 Ecological Research sites, exploring datasets in the data journal Ecological Archives, and

133 conducting literature searches. We initially identified 330 datasets spanning seven broad

134 taxonomic groups. We filtered these datasets to those meeting the following criteria: 1) each

135 assemblage was sampled on at least six occasions (typically years, but occasionally for smaller

136 organisms like plankton samples were monthly or bimonthly), 2) at least ten species were observed

137 over the course of the study, and 3) the study had a spatially well-defined location with a fixed

138 environmental context (e.g. communities based solely on the geographic coordinates of individual

139 organisms, as in many marine pelagic transect studies, were not included). Of the 330 datasets

140 examined, 86 satisfied our criteria and yielded 17,921 unique assemblages spanning terrestrial,

141 marine and freshwater ecosystems. A complete list of datasets and sources is provided in T. The

142 majority of datasets and community time series come from terrestrial bird and plant assemblages,

143 with fewer datasets from marine and freshwater systems (Figure 2A-D). The duration of the studies

144 ranged from six to 57 years and assemblage richness ranged from 10 to 276 species, with most

145 assemblages having between 20 and 61 species (Figure 2E, F). All species names were checked

146 for typos, and any taxa not identified to species (e.g. "Unidentified grass") were removed unless

147 the taxon clearly did not overlap with any other taxa in the dataset (e.g. "Sigmodon sp." was

148 retained only if no other Sigmodon species were present in the region). For datasets with uneven 

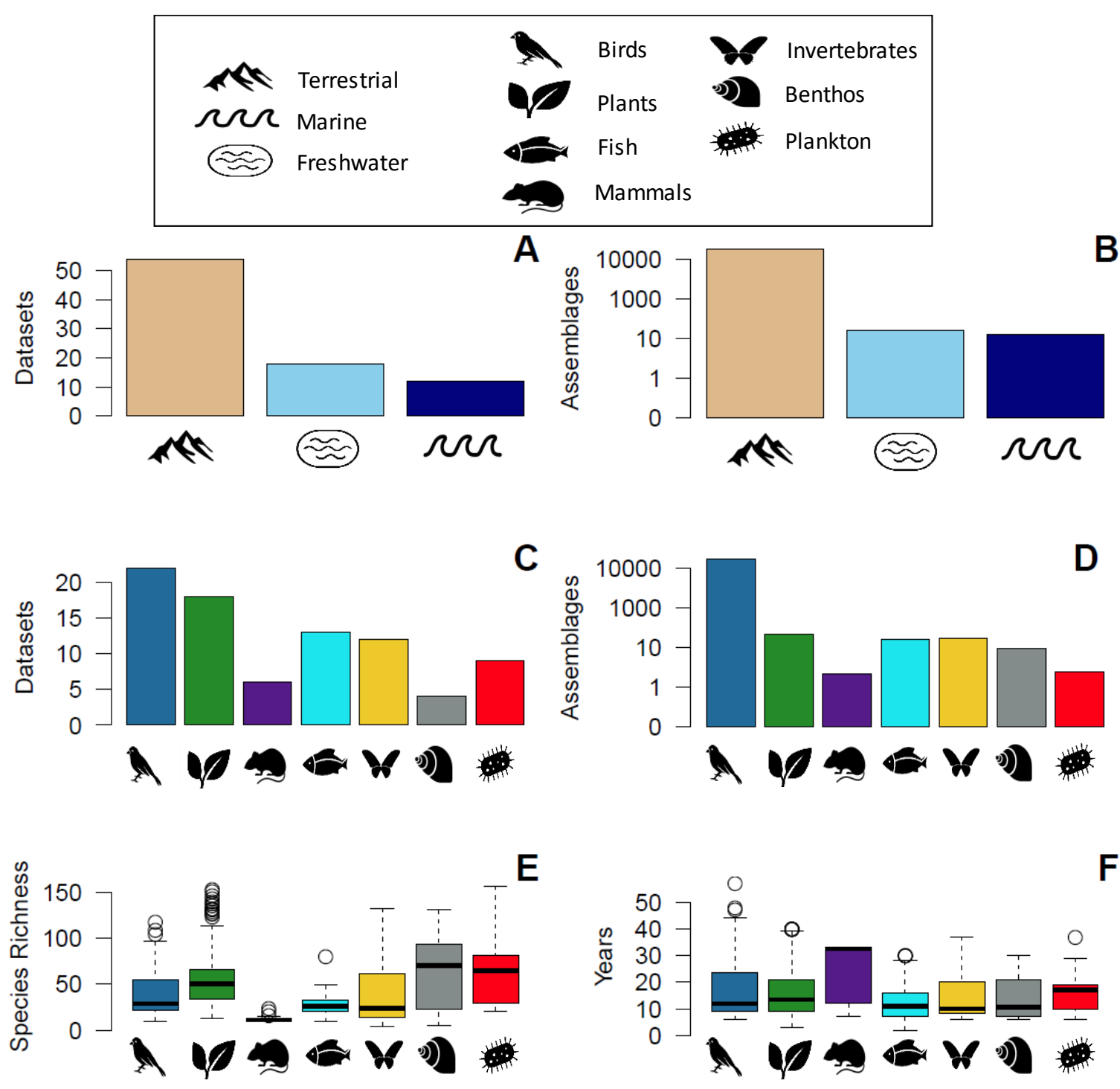

Figure 2. Description of the compiled time-series datasets. The number of (A) datasets and (B) number of assemblages (log scaled) by ecosystem type (terrestrial, freshwater, marine) and by taxonomic group (C, D). (E) Boxplots of the number of species per assemblage by taxonomic group. Several high richness outliers for plant and plankton assemblages were excluded to improve visualizing the bulk of the data $(*)$. (F) Boxplots of time series length by taxonomic group.

150 sampling in either space or time (e.g. variable numbers of surveys per year, or variable numbers

151 of spatial units per survey), we standardized the level of spatial or temporal subsampling for that

152 site in each year of the time series (see details in Appendix, Figure A1). 
154 Analysis

Following Coyle et al. (2013), we operationally defined a species as transient at a site

156 if it was observed in $33 \%$ or fewer of the temporal sampling intervals, and assessed the prevalence

157 of transients as the proportion of species in the assemblage below this threshold (Figure 1A). We

158 also evaluated more restrictive definitions using maximum temporal occupancy thresholds of $10 \%$

159 and $25 \%$ to evaluate the impact of this decision. Results were qualitatively similar for the three

160 different thresholds (Figure A2-A6).

161 Although many authors have used the bimodality of temporal occupancy distributions (e.g.,

162 Figure 1A) to identify transient species in this way (Magurran and Henderson 2003; Dolan et al.

163 2009; Coyle et al. 2013), some species will be incorrectly classified due to imperfect detectability.

164 Species with low detectability due to low density or traits or behaviors that make them difficult to

165 detect may be persistent at a site but only detected in a small proportion of samples (MacKenzie

166 et al. 2006). As such, estimates of the proportion of transient species based on observed temporal

167 occupancy are likely higher than the true numbers. A full exploration of the detailed influence of

168 imperfect detection is beyond the scope of this paper, but we are developing simulation-based

169 approaches to understand precisely how it influences estimates of the proportion of transients as

170 well as the identification of individual species (Hurlbert unpublished data).

171 While imperfect detection is clearly a concern for analyses of this type there is also

172 evidence that using observed occupancy provides a reasonable first approximation of transient

173 status. Magurran and Henderson (2003) showed that using occupancy to identify species as

174 transient is consistent with using habitat preferences. In an examination of nearly 500 bird

175 communities, Coyle et al. (2013) showed that transient species richness was correlated with 
176 regional habitat heterogeneity as would be expected of true transients while it was not positively

177 correlated with vegetation which would be expected to impede species detections. In addition,

178 similar studies using habitat preference-based transient designations (Belmaker 2009) have yielded

179 similar conclusions to those using occupancy based approaches (Coyle et al. 2013). Finally, the

180 results in this paper are similar for species that are comprehensively surveyed and those that are

181 less thoroughly sampled (see Results and Considerations). So, while there is no doubt that

182 misclassifications will occur, for large data compilations like this one that lack both detailed habitat

183 preference data for species and the necessary sampling methods to estimate detection probabilities,

184 occupancy based approaches appear to provide a reasonable approximate classification. We

185 address these issues further in the Considerations section of the Discussion.

We evaluated the effect of spatial scale on the perceived prevalence of transient species

187 using the subset of datasets that included sampling at hierarchically nested spatial scales. We used

188 a linear mixed model to quantify how the proportion of transient species in an assemblage varied

189 with the spatial scale over which the assemblage was characterized. The model included taxonomic

190 group as a fixed effect and dataset as a random effect, with both variables having the potential to

191 influence both the slope and intercept of the relationship. Area was log-transformed for analysis.

192 Because scale will be perceived differently for organisms of different size — e.g. a 1 ha quadrat is

193 effectively much larger for ants than for birds - it may not allow for direct comparisons of "scale"

194 among taxonomic groups. As such, we also built a similar mixed model using the median

195 community size for all assemblages (i.e., the total number of individuals sampled in an assemblage,

196 median $=102$ ) as an alternative, potentially more generalizable, measure of scale.

197 To explore the influence of habitat heterogeneity on the prevalence of transients we used a

198 linear mixed model to predict the proportion of transients as a function of elevational heterogeneity 
199 (the variance in elevation within a $5 \mathrm{~km}$ radius of the site), with spatial scale (using community

200 size as a proxy) as a covariate and taxonomic group as a random effect. P-values were estimated

201 from the $t$-statistics using a normal approximation. All terrestrial datasets with geographic

202 coordinates were used to fit the model. We used a 30 arc-second digital elevation model DEM of

203 North America (GTOPO30), acquired from the USGS Earth Resources Observation and Science

204 Center (EROS), to calculate the variance of elevation. We calculated a pseudo $\mathrm{R}^{2}$ for each mixed 205 model based on the fit between predicted and observed values.

Finally, we quantified the influence of transient species on a suite of commonly studied

207 ecological patterns including species-abundance distributions, species-area relationships, temporal

208 turnover, and correlates of species richness. We did this by comparing the form of these patterns

209 when using data on the entire community to the same pattern generated after excluding species

210 that were identified as transients (i.e. those species with temporal occupancy $\leq 33 \%$ ). We fit two

211 distributions for species-abundance, the logseries and the Poisson lognormal to the combined

212 abundance data across years for each time-series. Magurran and Henderson (2003) proposed that

213 transient species should be better fit by the logseries and core species by the lognormal, meaning

214 that excluding transient species should result in improved fits by the lognormal. We compared the

215 fits of the two distributions based on $\mathrm{AIC}_{\mathrm{c}}$ model weights. Analysis of species-area relationships

216 was restricted to datasets with hierarchical spatial sampling. Power function relationships were fit

217 to each assemblage using linear regression on log-transformed data (Xiao et al. 2011) to predict

218 the number of species observed from the area sampled. The fitted exponents of the relationships

219 were compared. Mean temporal turnover was calculated as the mean of the Jaccard dissimilarity

220 index (Krebs 1999; Figure 1E) between all adjacent time samples in each community time series.

221 Analyses of the drivers of species richness were restricted to data from the Breeding Bird Survey 
222 of North America since it was the only dataset that employed consistent sampling across large

223 spatial scales with a large number of replicates. For this last set of analyses we used two

224 environmental correlates that are known to be important for determining richness in this dataset,

225 the Normalized Difference Vegetation Index (NDVI), a remotely sensed estimate of productivity,

226 and elevation (White and Hurlbert 2010). We calculated correlation coefficients between each

227 environmental variable and species richness (including or excluding transient species), as well as

228 correlation coefficients for transient species richness alone to further illuminate differences.

229 The complete set of $\mathrm{R}$ scripts for data cleaning and processing are available on Github

230 (http://www.github.com/hurlbertlab/core-transient) and analysis scripts for this study are archived

231 at Data Dryad (URL to be filled in).

233 Results

Assemblages from all ecosystem types and taxonomic groups included a substantial 235 proportion of transient species, and relatively few species with intermediate temporal occupancies

236 (Figure 3). The proportion of an assemblage made up of transient species varied with taxonomic

237 group, with means ranging from 32-58\%. Benthos and invertebrates had more than 50\% of species

238 characterized as transient on average. Fish, plankton, and plant communities had 46-49\% transient

239 species on average. In mammal communities, $45 \%$ of species were classified as transient, while

240 birds had the lowest proportion of species classified as transients at $30 \%$. Terrestrial ecosystems

241 had the lowest proportion of transient species (37\%) followed by marine (48\%) and freshwater

$242(55 \%)$ systems (Figure 3B). 

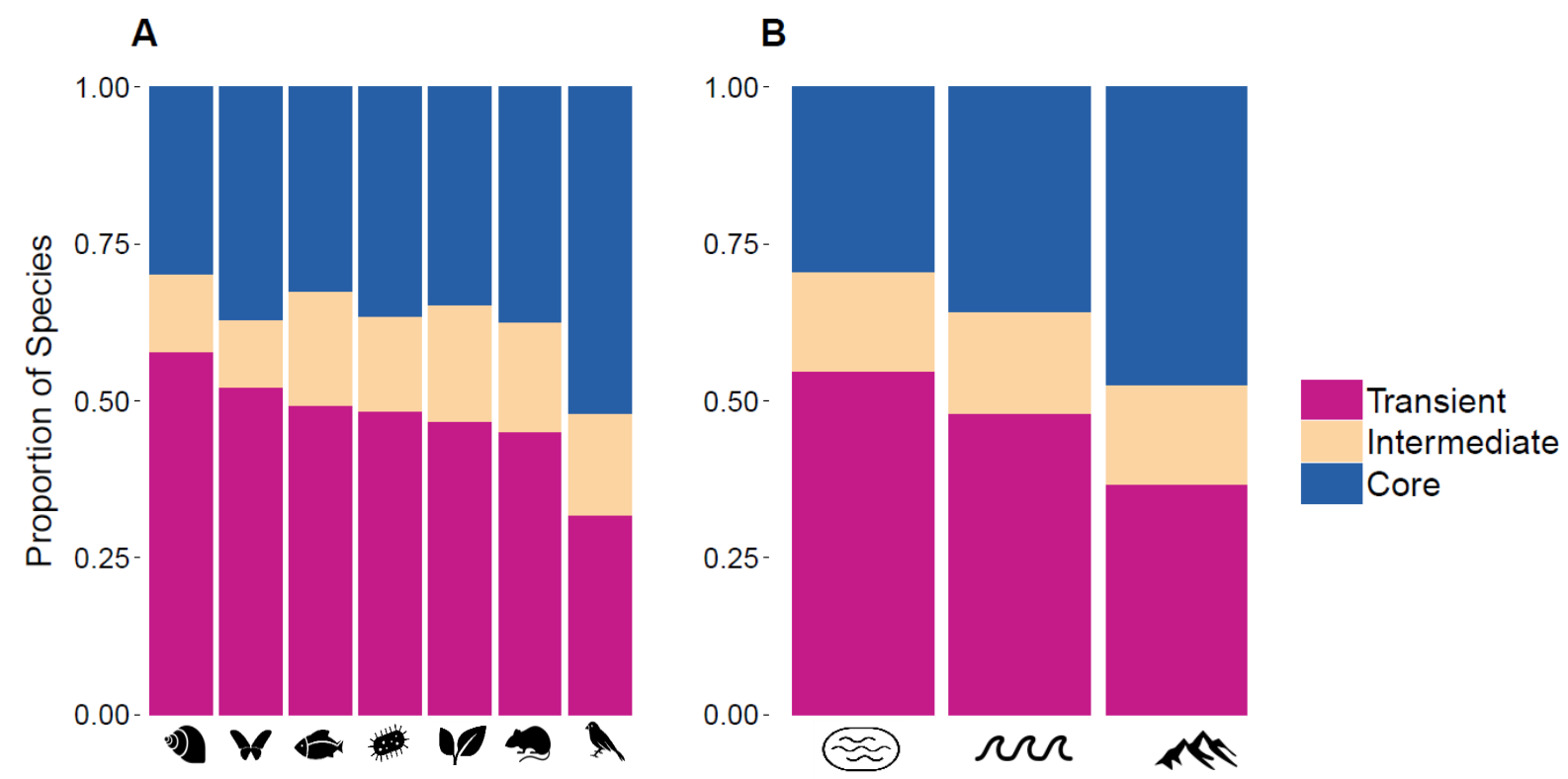

Figure 3. The mean proportion of species in an assemblage that are transient $(\leq 33 \%$ temporal occupancy), core (>66.7\%), or neither, grouped by (A) taxonomic group and (B) ecosystem. See Figure 2 for icon key.

There was a negative effect of sampling area on the proportion of transients in a community

$245\left(p<10^{-16}\right)$, but scaling relationships varied substantially in both slope and intercept across datasets

246 and taxonomic groups (Figure 4A; pseudo $\mathrm{R}^{2}=0.01$ ). When we characterized the scaling

247 relationships using total community size based on the total number of individuals in an average

248 sample instead of sample area the relationship was considerably stronger (Figure 4B; pseudo $\mathrm{R}^{2}=$

249 0.32). Communities at scales in which large numbers of individuals are sampled have few transient

250 species, while communities at scales in which small numbers of individuals are sampled have

251 proportionally more transient species, regardless of taxonomic group. After controlling for scale

252 (community size), birds - one of the taxonomic groups with the lowest representation of transient

253 species based on the raw survey data-became comparable to benthic and terrestrial invertebrates,

254 which had the highest representations of transient species based on raw data (cf. Figure 3A and 

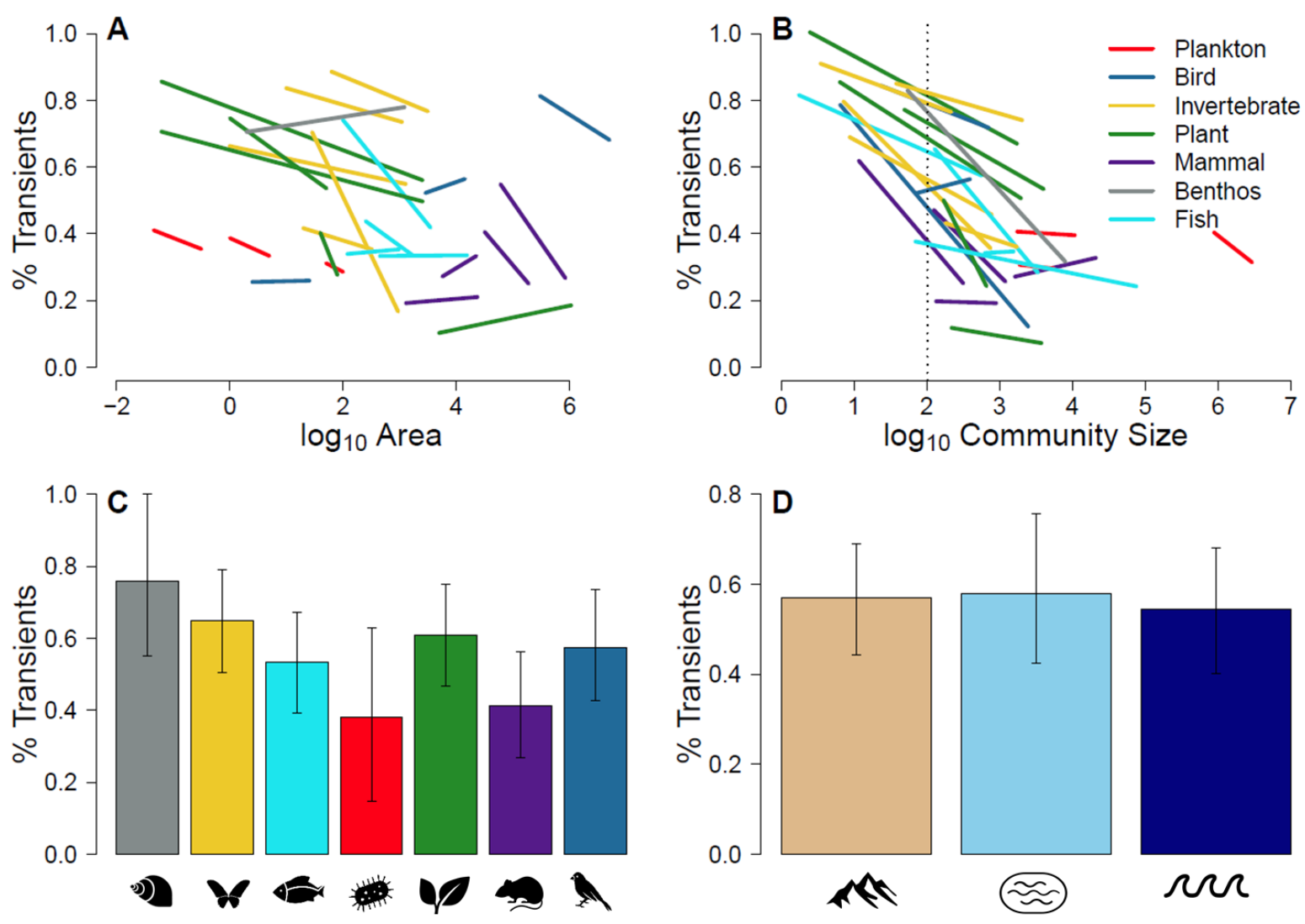

Figure 4. Linear models of the proportion of transient species as a function of (A) sample area and (B) sample community size (number of individuals) for each dataset with a spatially hierarchical sampling scheme. Datasets are color coded by taxonomic group. The proportion of transient species expected for a hypothetical community of 102 individuals (the median community size across datasets) for a given (C) taxonomic group or (D) ecosystem based on linear mixed effects models (see text). No spatially hierarchical datasets were available to evaluate benthic invertebrates. See Figure 2 for icon key.

4C). Mammal and plankton communities had the lowest average proportion of transient species in

256 scale-corrected datasets at approximately $40 \%$. Controlling for sampling scale, the proportion of

257 transients in an assemblage no longer varied across type of ecosystem (Figure 4D).

Elevational heterogeneity was found to have a positive effect $(p<0.0001)$ on the proportion

259 of transient species when accounting for community size as a covariate and taxonomic group as a

260 random effect (Table 1). There was no evidence for an interaction between elevational

261 heterogeneity and community size $(p=0.98)$. 
Table 1. Linear mixed model results for the effect of elevational heterogeneity and community size on the proportion of transients. Taxonomic group was included as a random effect.

\begin{tabular}{rcccc}
\hline Fixed Effect & Estimate & Standard Error & $\boldsymbol{t}$ & $\boldsymbol{p}$ \\
\hline Intercept & 1.08 & 0.054 & 20.0 & $<10^{-16}$ \\
$\log 10($ community size) & -0.23 & 0.006 & -36.35 & $<10^{-16}$ \\
$\log 10($ elev. variance) & 0.013 & 0.003 & 3.91 & $9.27 \mathrm{e}-5$ \\
$\log 10($ community size) $\log 10($ elev. variance) & $-4.3 \mathrm{e}-5$ & 0.002 & -0.027 & 0.98 \\
\hline
\end{tabular}

271 distribution (Figure 5A). The strength of species richness drivers varied depending on whether

272 transient species were included or not, because transient species exhibited environmental

273 correlations of opposite sign to non-transient species (Figure 5B). As such, excluding transient

274 species led to a stronger positive correlation between richness and the vegetation index NDVI,

275 (0.53 versus 0.48$)$, and a stronger negative correlation with mean elevation (-0.46 versus -0.37$)$.

276 Species turnover was always higher when transient species were included than when they were

277 excluded, with an average deviation of 0.11 (Figure 5C). Finally, the exponent of the species-area

278 relationship was typically higher when excluding transients (average deviation = 0.07; Figure 5D).

279 All results were similar using alternative occupancy thresholds to define transient species (Figures 280 A2-6). 

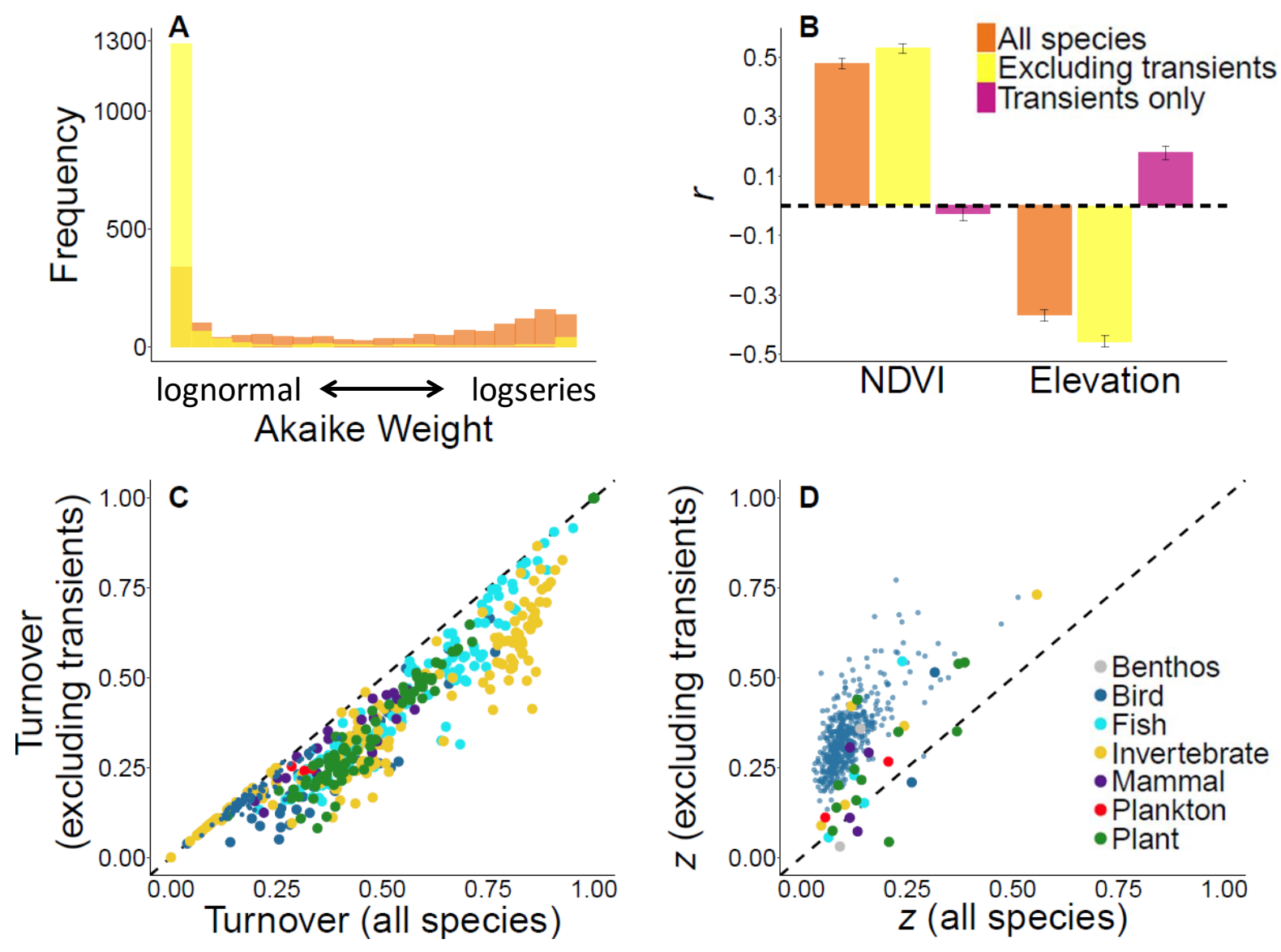

Figure 5. Comparison of common ecological patterns between full communities and communities excluding transient species. (A) Histogram of Akaike weights for the logseries model of the species abundance distribution for all species (orange) and excluding transients (yellow). Because only two models were compared, Akaike weights close to 0 imply strong support for the lognormal model. (B) Environmental correlates of species richness (NDVI and elevation) including transients (orange), excluding transients (yellow), and transients only (pink). (C) Comparison of temporal turnover estimates when including or excluding transient species. Temporal turnover was quantified using the Jaccard dissimilarity index. Points are color coded by taxa and small blue circles represent the North American Breeding Bird Survey. (D) Comparison of species-area relationship exponents when including or excluding transient species. Points are the same as in (C).

\section{Discussion}

We quantified the prevalence and impact of transient species in ecological communities

284 using data on over 17,000 community time series spanning multiple ecosystems, taxonomic 
and ecosystems examined, demonstrating that these species are a general feature of ecological systems. Transient species interact with their abiotic and biotic environment in distinct ways (Magurran and Henderson 2003; Ulrich and Ollik 2004; Coyle et al. 2013; Umaña et al. 2017), which highlights the need to better understand the contexts in which transient species are expected to be prevalent and the potential impact transient species may have on ecological inferences. community is related to spatial scale. For communities sampled at multiple spatial scales, the proportion of transient species decreased with increasing scale, as species were more likely to be observed and actually persist over larger sampling areas. As a result, comparisons of the prevalence of transient species between studies should account for scale. However, area per se may not be

297 space differently. An alternative measure of scale, community size, effectively controls for 298 differences in area usage between taxonomic groups by integrating the influence of each species’ 299 distinct life history traits and home range sizes. Correcting for scale in this way, we found that the 300 proportion of transient species did not vary with ecosystem type, whereas ignoring scale would 301 have led to the conclusion that transient species were much more common in freshwater than 302 terrestrial ecosystems. Similarly, correcting for scale led to a more even distribution of the 303 proportion of transient species across taxonomic groups, and some groups that would otherwise 304 have been inferred to differ substantially in the prevalence of transients were actually found to be 305 comparable. Differences in the prevalence of transient species were evident among taxonomic groups

307 even when controlling for spatial scale. Invertebrate, plant, and bird communities had the highest 308 proportion of transient species while plankton and mammal communities had the lowest. These 
taxonomic groups differ in many respects precluding a rigorous analysis, but we speculate that

310 traits such as dispersal ability and habitat specialization may increase the likelihood of species

311 being temporarily observed in areas where they are not well adapted and hence being recorded as

312 transients. For example, birds have strong dispersal ability relative to the other taxonomic groups

313 and there are numerous records of individuals spotted far outside their geographic range and in

314 unexpected habitats (Grinnell 1922). Similarly, plants with passive seed dispersal may be

315 transported great distances and may consequently be more likely to be observed in unsuitable

316 habitat (Willson 1993). Small mammals have more limited dispersal, which may explain why

317 mammal communities (dominated in our dataset by small mammal communities) have a lower

318 proportion of transient species on average. The plankton datasets examined in this study came

319 primarily from lakes, and low rates of dispersal between lakes could explain the low proportion of

320 transient species for this group.

321 In addition to dispersal, groups composed of more generalist species might be expected to

322 have a lower proportion of transient species because most species can maintain viable populations

323 in most locations. The low prevalence of transient species in plankton communities may also be

324 explained by this phenomenon, as Hutchinson (1961) noted "paradoxically" that most plankton

325 species are generalists that compete for the same limited resources. Specialist species, on the other

326 hand, will only maintain populations in select locations with suitable conditions, allowing mass

327 effects (Shmida and Wilson 1985) or accidental dispersal to result in transient occurrences in other

328 areas.

329 In addition to trait differences among taxa, variability in the prevalence of transient species

330 was related to environmental heterogeneity. Transient species were more prevalent in communities

331 with higher elevational heterogeneity, which extends the findings of Coyle et al. (2013) for birds 
332 to a broader range of taxa. Homogeneous landscapes tend to have homogeneous communities

333 (Stegen et al. 2013; Stein et al. 2014) and a site within such a landscape is unlikely to receive

334 immigrants from poorly adapted species compared to a site in a heterogeneous landscape with a

335 more diverse species pool from more diverse habitats. Indeed, environmental heterogeneity and

336 species richness are frequently positively related (Stein et al. 2014), and our results indicate this

337 may be due in part to an increase in transient species rather than an increase in habitat specialists

338 (Gaston et al. 2007; Stein et al. 2014).

Impacts of Transient Species on Ecological Inference

342 patterns we examined, from measures of local community structure, to spatial and temporal

343 turnover, to richness gradients at continental scales. This highlights the importance of considering

344 transients when trying to manage and understand ecological communities. The species abundance

345 distribution (SAD) characterizes the relative abundance of common and rare species in

346 communities and different distributions have been associated with different processes structuring

347 the community (McGill et al. 2007; Connolly et al. 2014). Building on the results of Magurran and

348 Henderson (2003), we show that including transient species in an analysis results in more

349 logseries-like SADs while excluding them results in more lognormal distributions. This result is

350 consistent with the idea that different processes influence the community assembly of transient

351 versus core species (Henderson and Magurran 2014; Supp et al. 2015). Based on theoretical

352 grounds, many SAD models may be more appropriately applied to all species observed, or only to

353 the set of species that strongly interact and maintain viable populations. For example, neutral

354 theory applies to all species, as it explicitly allows for rare immigration or speciation events 
355 (Hubbell 2001), whereas resource allocation based niche apportionment models (MacArthur 1957;

356 Tokeshi 1990) are likely more appropriately applied only to non-transient species. While the SAD

357 may not be sufficient on its own to infer community structuring processes (Cohen 1968; Volkov

358 et al. 2005; Baldridge et al. 2016; but see Connolly et al. 2014), it is one of several ecological

359 patterns that may collectively shed light on such mechanisms (McGill et al. 2007; Blonder et al.

360 2014). As such, consideration of transient species has the potential to influence our understanding

361 of local community structure.

In addition to influencing measures of local community structure, the inclusion of transient

363 species also affected measures of how ecological systems turnover and change with scale.

364 Estimates of temporal turnover were always higher when transients were included in assemblages.

365 This occurs because transient species are only present over a small fraction of a time series,

366 resulting in higher turnover in species composition within a community over time (see also

367 Magurran and Henderson 2010). Conversely, the inclusion of transient species led to lower

368 estimates of spatial turnover as reflected in the slope of species-area relationships. This is because

369 a greater proportion of the species list at small spatial scales is identified as transient compared to

370 at a larger scale. As such, including transient species increases richness more at small scales than

371 large, resulting in a shallower species-area relationship and lower spatial turnover (Figure 1D).

372 Turnover and associated scaling relationships have implications for assessment of community

373 responses to global change (Brown et al. 1997; Suding et al. 2008), understanding processes

374 structuring spatiotemporal variation in communities (Adler et al. 2005; McGlinn and Palmer

375 2009), and up and downscaling biodiversity estimates for conservation (Shen and He 2008; Azaele

376 et al. 2015; Kitzes and Harte 2015), further indicating that consideration of transients is important

377 for understanding local to regional scale ecological systems. 
Finally, inclusion of transient species also influenced the strength of continental scale

379 correlates of species richness. Excluding transient species increased the explanatory power of both

380 NDVI and elevational heterogeneity. Transient species correlations were opposite of those

381 observed for core species, consistent with our general findings on the relationships between

382 environment and heterogeneity (Coyle et al. 2013). Because the proportion of transient species

383 varies along environmental gradients, analyses at large scales will potentially weight core and

384 transient species differently in different locations and the perceived importance of environmental

385 associations with ecological patterns may often change when excluding transient species. In this

386 example, the inclusion of transients weakens the perceived support for a species-energy

387 relationship (Wright 1983; Hurlbert 2004) compared to when only non-transients were considered.

388 Given the impact on a wide range of ecological patterns, the decision to include or exclude

389 transient species in a community analysis is an important one that should be made by explicitly

390 considering the nature of the conceptual framework or theory being investigated. In some cases, it

391 will be necessary to remove these species from analyses or risk making improper inferences.

\section{Considerations}

Conceptually, transient species are those that do not maintain persistent populations over

395 time and therefore only appear infrequently during surveys. The bimodality of temporal occupancy

396 distributions (e.g., Figure 1A) has led many authors to suggest that temporal occupancy can be

397 used to distinguish these transient species from more core members of a community. However, it

398 can be difficult to tease apart whether species of low occupancy are truly transient or simply have

399 low density or detectability (Henderson and Magurran 2014). We followed Coyle et al. (2013) in

400 using a maximum occupancy threshold of $33 \%$ as our operational definition of transient species, 
401 but all of the results we report here were similar using stricter thresholds of $10 \%$ or $25 \%$ (Figures

402 A2-A6). If the focus were on a single community, then the accuracy of identifying transient species

403 might be improved by a combination of assessing the shape and natural break points of each

404 community's particular occupancy distribution, and incorporating information on species habitat

405 preference as done by Belmaker (2009) for coral reef fish. Alternatively, when the sampling design

406 allows for the estimation of detection probabilities it should be possible to correct for these issues

407 using occupancy modeling (MacKenzie et al. 2006). Independent validation of transient status

408 (e.g., by evidence of breeding, or knowledge of habitat affinities) or occupancy modeling based

409 approaches are always desirable when possible, and analyses along environmental gradients

410 should carefully consider how detectability might vary along such gradients (Coyle et al. 2013).

411 However, for many groups detailed information on habitat preferences or estimates of true

412 population persistence is not readily available, and a definition based on a universal occupancy

413 threshold is currently the most feasible option for analyzing hundreds or thousands of assemblages

414 for cross-taxon comparisons like those presented here.

As described in the Methods, there is evidence that occupancy based thresholds provide

416 reasonable identifications of transient species (Magurran and Henderson 2003; Belmaker 2009;

417 Coyle et al. 2013). There is additional evidence from our results that using this raw occupancy

418 based approach provides a reasonable approximate classification. First, the misclassification rate

419 should presumably be lower when defining transient species using stricter occupancy thresholds,

420 and so the consistency of our results across multiple thresholds lends some confidence to this

421 approach. Second, for certain communities the taxonomic group and mode of data collection

422 provide nearly complete censuses of all individuals within a static sample (e.g. plant stems within

423 a quadrat or fish in a seine net). In these communities, imperfect detection should have little 
424 influence on estimates of occupancy (at the scale of sampling). The similarity of results in this

425 study across groups that tend to be thoroughly surveyed (e.g., plants and fish) and those that are

426 less intensively sampled (e.g., birds and butterflies) suggests that our results are not driven heavily

427 my misclassifying imperfectly detected species. A detailed understanding of when and to what

428 extent imperfect detection probabilities influence the assessment of the prevalence and impact of

429 transient species will require simulation based approaches (Hurlbert unpublished data).

431 Conclusions

433 all taxa, scales, and ecosystems examined. Despite the ubiquity of these species, most studies in 434 community ecology have implicitly ignored this concept by characterizing communities using 435 surveys that provide a snapshot of community composition in time. Because transient species 436 interact with their biotic and abiotic environment differently — in most cases, more weakly — than

437 non-transient species, their inclusion in community analyses impacts a wide range of ecological

438 patterns including estimates of community structure, turnover, and biodiversity. Ecologists should 439 explicitly consider whether to include or exclude transient species in analyses by determining 440 whether the theories, conceptual frameworks, and conservation interests of their research are best 441 aligned with entire communities including transient species or with only core species that maintain

442 sustained populations at a site. A failure to do so may result in inappropriate tests of models,

443 incorrect inferences regarding processes, and imperfect conservation efforts. When data are 444 unavailable for distinguishing species in a community as transient or not, researchers should be 445 aware of how this uncertainty may bias their results. While some methodological challenges 446 remain, future studies will benefit from considering when and how the inclusion of transient 
447 species impacts our understanding of how communities respond to environmental gradients,

448 habitat fragmentation, climatic shifts, and other disturbances.

449

450

451

452

453

454

455

456

457

458

459

460

461

462

463

464

465

466

467 Ecological Research Program (LTER) including DEB-0620652 and DEB-1234162. Further

468 support was provided by the Cedar Creek Ecosystem Science Reserve and the University of 469

470

\section{Acknowledgements}

This research was supported the National Science Foundation through grant DEB-1354563 to A.H.

Hurlbert and E.P. White and by the Gordon and Betty Moore Foundation's Data-Driven Discovery Initiative through Grant GBMF4563 to E.P. White. Taxa and ecosystem symbols are from the nounproject.com and are credited as follows: bird - parkjisun, plant - Delwar Hossain, mammal Francisca Arévalo, fish - Iconic, butterfly - Jacqueline Fernandes, snail - B Barrett, plankton Boris Belov, mountain - Alice Noir, waves - Alex Muravev, lake - Anton Gajdosik. The following datasets requested specific acknowledgements. Toolik LTER: This material is based upon work supported by the National Science Foundation under Grants \#DEB-1026843, 981022, 9211775, 8702328; \#OPP-9911278, 9911681, 9732281, 9615411, 9615563, 9615942, 9615949, 9400722, 9415411, 9318529; \#BSR 9019055, 8806635, 8507493. Any opinions, findings, conclusions, or recommendations expressed in the material are those of the author(s) and do not necessarily reflect the views of the National Science Foundation. Kellogg Biological Station: Support for this research was also provided by the NSF Long-term Ecological Research Program (DEB 1637653) at the Kellogg Biological Station and by Michigan State University AgBioResearch. Cedar Creek: This work was supported by grants from the US National Science Foundation Long-Term Minnesota. Konza Prairie LTER: Data for Plant species composition on selected watersheds at Konza Prairie, Konza LTER small mammals, Konza LTER grasshopper monitoring, Weekly 
471 record of bird species observed on Konza Prairie, and Fish population on selected watersheds at

472 Konza Prairie was supported by the NSF Long Term Ecological Research Program at Konza

473 Prairie Biological Station. Hubbard Brook: Data on the Bird Abundances at the Hubbard Brook

474 Experimental Forest (1969-present) and on three replicate plots (1986-2000) in the White

475 Mountain National Forest were provided by Richard Holmes on 6/16/2016. These data were

476 gathered as part of the Hubbard Brook Ecosystem Study (HBES). The HBES is a collaborative

477 effort at the Hubbard Brook Experimental Forest, which is operated and maintained by the USDA

478 Forest Service, Northern Research Station, Newtown Square, PA. Significant funding for

479 collection of these data was provided by DEB 0423259 (Hubbard Brook Long Term Ecological

480 Research). Sevilleta LTER: Sevilleta LTER mammals data set was provided by the Sevilleta Long

481 Term Ecological Research (LTER) Program. Significant funding for collection of these data was

482 provided by the National Science Foundation Long Term Ecological Research program (NSF

483 Grant numbers BSR 88-11906, DEB 9411976, DEB 0080529 and DEB 0217774). Maryland

484 Biological Stream Survey: Data included in this document were provided by the Maryland

485 Department of Natural Resources Monitoring and Non-tidal Assessment Division. Lake

486 Kasumigaura: The Lake Kasumigaura database, Table 10 Phytoplankton density, Lake

487 Kasumigaura database, Table 12-1 Density of Rotifer, Cladocera and Copepoda, Lake

488 Kasumigaura database, Table 14-1 Benthos data, and Lake Kasumigaura database, Table 15-2 Fish

489 density data are those of the Lake Kasumigaura Long-term Environmental Monitoring Program of

490 the National Institute for Environmental Studies, Japan. Data collection for the icthyoplankton

491 time series northeast of Taiwan was supported by the Council of Agriculture and the Ministry of

492 Science and Technology, Taiwan (to $\mathrm{CHH}$ ). We are grateful to the thousands of scientists and

493 volunteers who have helped to collect and share all of the data analyzed herein. 


\section{References}

Adler, P. B., E. P. White, W. K. Lauenroth, D. M. Kaufman, A. Rassweiler, and J. A. Rusak. 2005. Evidence for a General Species-Time-Area Relationship. Ecology 86:20322039.

Azaele, S., A. Maritan, S. J. Cornell, S. Suweis, J. R. Banavar, D. Gabriel, and W. E. Kunin. 2015. Towards a unified descriptive theory for spatial ecology: predicting biodiversity patterns across spatial scales. Methods in Ecology and Evolution 6:324-332.

Baldridge, E., D. J. Harris, X. Xiao, and E. P. White. 2016. An extensive comparison of speciesabundance distribution models. PeerJ 4:e2823.

Belmaker, J. 2009. Species richness of resident and transient coral-dwelling fish responds differentially to regional diversity. Global Ecology and Biogeography 18:426-436.

Blonder, B., L. Sloat, B. J. Enquist, and B. McGill. 2014. Separating Macroecological Pattern and Process: Comparing Ecological, Economic, and Geological Systems. Plos One 9:e112850.

Brown, J. H., T. J. Valone, and C. G. Curtin. 1997. Reorganization of an arid ecosystem in response to recent climate change. Proceedings of the National Academy of Sciences 94:9729-9733.

Cohen, J. E. 1968. Alternate derivations of a species-abundance relation. The American Naturalist 102:165-172.

Connolly, S. R., M. A. MacNeil, M. J. Caley, N. Knowlton, E. Cripps, M. Hisano, L. M. Thibaut, et al. 2014. Commonness and rarity in the marine biosphere. Proceedings of the National Academy of Sciences 111:8524-8529. 
517 Costello, M. J., and A. A. Myers. 1996. Marine Biodiversity Turnover of transient species as a

518 contributor to the richness of a stable amphipod (Crustacea) fauna in a sea inlet. Journal of Experimental Marine Biology and Ecology 202:49-62.

520 Coyle, J. R., Hurlbert Allen H., and E. P. White. 2013. Opposing Mechanisms Drive Richness Patterns of Core and Transient Bird Species. The American Naturalist 181:E83-E90.

522 Dolan, J. R., M. E. Ritchie, A. Tunin-Ley, and M.-D. Pizay. 2009. Dynamics of core and occasional species in the marine plankton: tintinnid ciliates in the north-west Mediterranean Sea. Journal of Biogeography 36:887-895.

525 Dornelas, M., N. J. Gotelli, B. McGill, H. Shimadzu, F. Moyes, C. Sievers, and A. E. Magurran. 2014. Assemblage Time Series Reveal Biodiversity Change but Not Systematic Loss.

531 Grinnell, J. 1922. The Role of The "Accidental." The Auk 39:373-380.

532 Henderson, P. A., and A. E. Magurran. 2014. Direct evidence that density-dependent regulation underpins the temporal stability of abundant species in a diverse animal community. University Press.

537 Hurlbert, Allen H. 2004. Species-energy relationships and habitat complexity in bird communities. Ecology Letters 7:714-720.

539 Hutchinson, G. E. 1961. The Paradox of the Plankton. The American Naturalist 95:137-145. 
540 Kitzes, J., and J. Harte. 2015. Predicting extinction debt from community patterns. Ecology 96:2127-2136.

542 Krebs, C. . 1999. Ecological Methodology (2nd ed.). Addison-Wesley Educational Publishers, $543 \quad$ Inc.

544 MacArthur, R. H. 1957. On the relative abundance of bird species. Proceedings of the National Academy of Sciences of the United States of America 43:293-295.

546 MacKenzie, D. I., J. D. Nichols, A. Royle, K. H. Pollock, L. L. Bailey, and J. E. Hines. 2006. Bimodal occupancy-frequency distributions uncover the importance of regional

550 Magurran, A. E., and P. A. Henderson. 2003. Explaining the excess of rare species in natural species abundance distributions. Nature 422:714-716.

552 Magurran and Henderson. 2010. Temporal turnover and the maintenance of diversity in ecological assemblages. Philosophical Transactions of the Royal Society of London B: Biological Sciences 365:3611-3620.

555 McGill, B. J., R. S. Etienne, J. S. Gray, D. Alonso, M. J. Anderson, H. K. Benecha, M. Dornelas, et al. 2007. Species abundance distributions: moving beyond single prediction theories to integration within an ecological framework. Ecology Letters 10:995-1015.

558 McGlinn, D. J., and M. W. Palmer. 2009. Modeling the sampling effect in the species-time-area relationship. Ecology 90:836-846.

560 Novotný, V., and Y. Basset. 2000. Rare species in communities of tropical insect herbivores: pondering the mystery of singletons. Oikos 89:564-572. 
562 Petersen, E. D. S., L. C. Rossi, and M. V. Petry. 2015. Records of vagrant bird species in

563 Antarctica: new observations. Marine Biodiversity Records 8:e61 (6 pages).

564 Shen, T.-J., and F. He. 2008. An Incidence-Based Richness Estimator for Quadrats Sampled

565 Without Replacement. Ecology 89:2052-2060.

566 Shmida, A., and M. V. Wilson. 1985. Biological Determinants of Species Diversity. Journal of

$567 \quad$ Biogeography 12:1-20.

568 Southwood, T. R. E., V. C. Moran, and C. E. J. Kennedy. 1982. The Richness, Abundance and Biomass of the Arthropod Communities on Trees. Journal of Animal Ecology 51:635649.

571 Stegen, J. C., A. L. Freestone, T. O. Crist, M. J. Anderson, J. M. Chase, L. S. Comita, H. V. Cornell, et al. 2013. Stochastic and deterministic drivers of spatial and temporal turnover in breeding bird communities. Global Ecology and Biogeography 22:202212.

575 Stein, A., K. Gerstner, and H. Kreft. 2014. Environmental heterogeneity as a universal driver of species richness across taxa, biomes and spatial scales. Ecology Letters 17:866-880.

577 Suding, K. N., S. Lavorel, F. S. Chapin, J. H. C. Cornelissen, S. Díaz, E. Garnier, D. Goldberg, et al. 2008. Scaling environmental change through the community-level: a trait-based response-and-effect framework for plants. Global Change Biology 14:1125-1140.

580 Supp, S. R., D. N. Koons, and S. K. M. Ernest. 2015. Using life history trade-offs to understand core-transient structuring of a small mammal community. Ecosphere 6:1-15.

582 Tokeshi, M. 1990. Niche Apportionment or Random Assortment: Species Abundance Patterns Revisited. Journal of Animal Ecology 59:1129-1146. 
584 Ulrich, W., and M. Ollik. 2004. Frequent and occasional species and the shape of relativeabundance distributions. Diversity and Distributions 10:263-269. for trait-based community ecology: an example from a tropical tree seedling community. Ecology Letters.

Volkov, I., J. R. Banavar, F. He, S. P. Hubbell, and A. Maritan. 2005. Density dependence explains tree species abundance and diversity in tropical forests. Nature 438:658-661.

White, A. E. 2016. Geographical Barriers and Dispersal Propensity Interact to Limit Range Expansions of Himalayan Birds. The American Naturalist 188:99-112.

White, E. P., and A. H. Hurlbert. 2010. The Combined Influence of the Local Environment and E43.

Willson, M. F. 1993. Dispersal Mode, Seed Shadows, and Colonization Patterns. Vegetatio 107/108:260-280.

Wright, D. H. 1983. Species-Energy Theory: An Extension of Species-Area Theory. Oikos $41: 496-506$. vs. nonlinear regression for analyzing biological power laws. Ecology 92:1887-1894. 


\section{Appendix}

Sampling standardization of community time series datasets

For the most accurate estimates of temporal occupancy, the sampling intensity used to

613 characterize the assemblage in question should be identical every year. However, for some

614 datasets, sampling intensity was not uniform in space or in time. In some cases, the number of

615 spatial units (e.g. plant quadrats) censused varied by sampling date, in other cases, the number of

616 sampling dates per year with which an assemblage could be characterized varied between years,

617 and occasionally both spatial and temporal subsampling levels varied.

619 with which an assemblage is characterized over its time series. Choosing the number of spatial or

620 temporal subsamples to use for rarefaction is a non-trivial problem, however. On the one hand,

621 the lowest common level of subsampling across years or sites might be chosen which will enable

622 the inclusion of all years or sites available in the dataset. In this case, data from the best sampled

623 sites or years will be thrown out during rarefaction in order to compare those sites or years with

624 the less well sampled ones. On the other hand, one might choose a high level of subsampling

625 which will provide a more thorough characterization of those well sampled assemblages. In this

626 case, data will be lost as many sites or years will not meet this high threshold and so will not be

627 included in the analysis.

For each dataset, we attempted to maximize both the number of assemblages that

629 would be available for analysis as well as the thoroughness with which an assemblage was

630 characterized by choosing the lowest level of subsampling that was met by at least $50 \%$ of

631 possible site-years (Figure A1). 
A

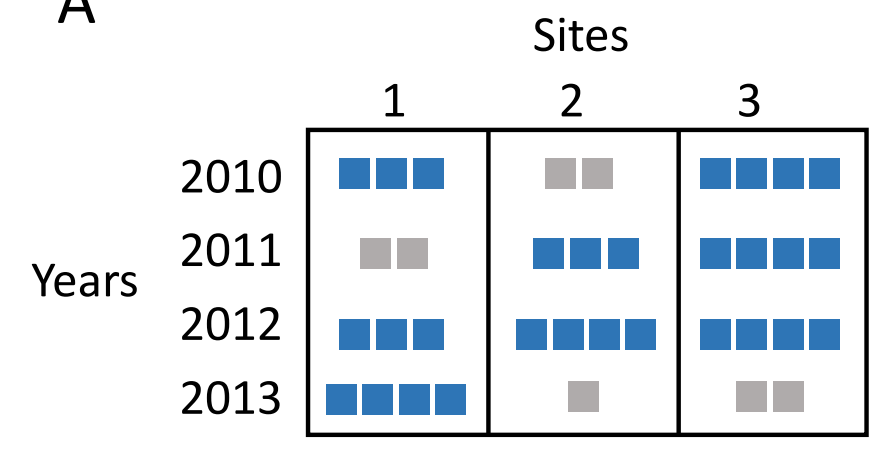

B

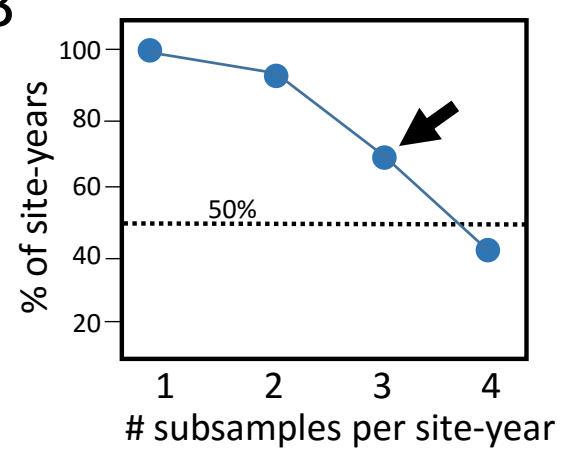

Figure A1. (A) A hypothetical dataset with 3 sites that have been sampled with variable intensity over time (squares). Site-years exceeding the threshold of 3 subsamples are highlighted in blue. Only data from these site-years would be used in an analysis, and where the total number of subsamples exceeds the threshold, only 3 would be chosen at random to characterize an assemblage. (B) The subsampling threshold is the smallest value for which the $\%$ of available site-years exceeds $50 \%$ (dotted line). 
Table A1. Table of datasets, sources, and citations used for analyses.

\begin{tabular}{|c|c|c|c|c|c|c|c|c|}
\hline Dataset Name & Link & System & Taxa & $\begin{array}{l}\text { Number } \\
\text { of Sites }\end{array}$ & $\begin{array}{l}\text { Years of } \\
\text { Study }\end{array}$ & $\begin{array}{l}\text { Number } \\
\text { of Species }\end{array}$ & $\begin{array}{l}\text { Multi- } \\
\text { scale }\end{array}$ & Citation \\
\hline $\begin{array}{l}\text { A multi-decade time series of kelp } \\
\text { forest community structure at the } \\
\text { California Channel Islands }\end{array}$ & http://esapubs.org/archive/ecol/E094/245/ & Marine & Benthos & 33 & 30 & 28 & $\mathrm{~N}$ & $\begin{array}{l}\text { Kushner et al. } \\
2013\end{array}$ \\
\hline $\begin{array}{l}2003 \text { Prescribed Burn Effect on } \\
\text { Chihuahuan Desert Grasses and } \\
\text { Shrubs at the Sevilleta National } \\
\text { Wildlife Refuge, New Mexico: } \\
\text { Species Composition Study ( } 2004 \\
\text { - present) }\end{array}$ & http://sev.lternet.edu/data/sev-166 & Terrestrial & Plant & 16 & 9 & 147 & $\mathrm{Y}$ & $\begin{array}{l}\text { Muldavin and } \\
\text { Collins } 2016\end{array}$ \\
\hline $\begin{array}{l}\text { A 12-year study on the scaling of } \\
\text { vascular plant composition in an } \\
\text { Oklahoma tallgrass prairie }\end{array}$ & $\begin{array}{l}\text { http://esapubs.org/Archive/ecol/E091/124/default. } \\
\text { htm\#data }\end{array}$ & Terrestrial & Plant & 20 & 12 & 318 & $\mathrm{Y}$ & $\begin{array}{l}\text { McGlinn et al. } \\
2010\end{array}$ \\
\hline $\begin{array}{l}\text { A long-term bird population study } \\
\text { in an Appalachian spruce forest }\end{array}$ & http://www.jstor.org/stable/4161914 & Terrestrial & Bird & 1 & 22 & 20 & $\mathrm{~N}$ & Hall 1984 \\
\hline
\end{tabular}




\begin{tabular}{|c|c|c|c|c|c|c|c|c|}
\hline $\begin{array}{l}\text { A multi-decade time series of kelp } \\
\text { forest community structure at San } \\
\text { Nicolas Island, California (USA): } \\
\text { benthic cover }\end{array}$ & http://esapubs.org/archive/ecol/E094/244/\#data & Marine & Benthos & 7 & 27 & 128 & $\mathrm{Y}$ & $\begin{array}{l}\text { Kenner et al. } \\
2013\end{array}$ \\
\hline $\begin{array}{l}\text { A multi-decade time series of kelp } \\
\text { forest community structure at San } \\
\text { Nicolas Island, California (USA): } \\
\text { benthic fish }\end{array}$ & http://esapubs.org/archive/ecol/E094/244/\#data & Marine & Fish & 7 & 26 & 36 & $\mathrm{Y}$ & $\begin{array}{l}\text { Kenner et al. } \\
2013\end{array}$ \\
\hline $\begin{array}{l}\text { A multi-decade time series of kelp } \\
\text { forest community structure at San } \\
\text { Nicolas Island, California (USA): } \\
\text { midwater fish }\end{array}$ & http://esapubs.org/archive/ecol/E094/244/\#data & Marine & Fish & 1 & 17 & 57 & $\mathrm{Y}$ & $\begin{array}{l}\text { Kenner et al. } \\
2013\end{array}$ \\
\hline $\begin{array}{l}\text { A multi-decade time series of kelp } \\
\text { forest community structure at the } \\
\text { California Channel Islands }\end{array}$ & http://esapubs.org/archive/ecol/E094/245/ & Marine & Fish & 32 & 16 & 86 & $\mathrm{~N}$ & $\begin{array}{l}\text { Kushner et al. } \\
2013\end{array}$ \\
\hline $\begin{array}{l}\text { Above ground plant biomass in a } \\
\text { mesic acidic tussock tundra } \\
\text { experimental site from } 1982 \text { to }\end{array}$ & $\begin{array}{l}\text { http://arc- } \\
\text { lter.ecosystems.mbl.edu/19822000gs81tusbm }\end{array}$ & Terrestrial & Plant & 4 & 6 & 24 & $\mathrm{Y}$ & Shaver 2006 \\
\hline
\end{tabular}




\begin{tabular}{|c|c|c|c|c|c|c|c|c|}
\hline $\begin{array}{l}2000 \text { Arctic LTER, Toolik Lake, } \\
\text { Alaska }\end{array}$ & & & & & & & & \\
\hline $\begin{array}{l}\text { An efficient light-trap for catching } \\
\text { insects. Acta Entomologica }\end{array}$ & http://www3.imperial.ac.uk/cpb/databases/gpdd & Terrestrial & Invertebrate & 1 & 26 & 133 & $\mathrm{~N}$ & Novak 1983 \\
\hline $\begin{array}{l}\text { Arthropod Pitfall Traps at LTER } \\
\text { II NPP sites. Jornada LTER }\end{array}$ & http://jornada.nmsu.edu/lter/project/49395/view & Terrestrial & Invertebrate & 10 & 6 & 157 & $\mathrm{Y}$ & $\begin{array}{l}\text { Lightfoot et al. } \\
2008\end{array}$ \\
\hline $\begin{array}{l}\text { Belgian Migrating Lepidoptera } \\
\text { Survey }\end{array}$ & $\begin{array}{l}\text { https://web.archive.org/web/19990220041409/http } \\
\text { ://users.skynet.be/bs663526/ }\end{array}$ & Terrestrial & Invertebrate & 1 & 14 & 25 & $\mathrm{~N}$ & $\begin{array}{l}\text { Vanholder } \\
1997\end{array}$ \\
\hline $\begin{array}{l}\text { Bialowieza National Park bird } \\
\text { assemblage }\end{array}$ & $\begin{array}{l}\text { http://www.bioone.org/doi/abs/10.3161/00016451 } \\
\text { 0X551354 }\end{array}$ & Terrestrial & Bird & 7 & 40 & 84 & $\mathrm{~N}$ & $\begin{array}{l}\text { Wesołowski et } \\
\text { al. } 2010\end{array}$ \\
\hline $\begin{array}{l}\text { Breeding Bird Populations at } \\
\text { William Trelease Woods }\end{array}$ & http://hdl.handle.net/2142/25182 & Terrestrial & Bird & 1 & 44 & 60 & $\mathrm{~N}$ & Kendeigh 1982 \\
\hline $\begin{array}{l}\text { Breeding Bird Populations on } \\
\text { Abandoned Farmland in Robert } \\
\text { Allerton Park }\end{array}$ & http://hdl.handle.net/2142/25182 & Terrestrial & Bird & 1 & 6 & 34 & $\mathrm{~N}$ & Kendeigh 1982 \\
\hline
\end{tabular}




\begin{tabular}{|c|c|c|c|c|c|c|c|c|}
\hline $\begin{array}{l}\text { Breeding Bird Populations on } \\
\text { Abandoned Farmland in Robert } \\
\text { Allerton Park }\end{array}$ & http://hdl.handle.net/2142/25182 & Terrestrial & Bird & 1 & 25 & 53 & $\mathrm{~N}$ & Kendeigh 1982 \\
\hline $\begin{array}{l}\text { Breeding Bird Populations } \\
\text { wintering in William Trelease } \\
\text { Woods }\end{array}$ & http://hdl.handle.net/2142/25182 & Terrestrial & Bird & 1 & 48 & 48 & $\mathrm{~N}$ & Kendeigh 1982 \\
\hline $\begin{array}{l}\text { Breeding Bird Censuses, } \\
\text { Neotoma }\end{array}$ & http://www.jstor.org/stable/1931793 & Terrestrial & Bird & 1 & 10 & 56 & $\mathrm{~N}$ & Preston 1960 \\
\hline Canadian duck censuses & $\begin{array}{l}\text { http://ecologicaldata.org/wiki/redvers-waterfowl- } \\
\text { census }\end{array}$ & Terrestrial & Bird & 2 & 26 & 13 & $\mathrm{~N}$ & $\begin{array}{l}\text { Vickery et al. } \\
1984\end{array}$ \\
\hline $\begin{array}{l}\text { Central California Butterfly } \\
\text { Population Monitoring }\end{array}$ & http://butterfly.ucdavis.edu/ & Terrestrial & Invertebrate & 8 & 41 & 148 & $\mathrm{~N}$ & $\begin{array}{l}\text { Thorne et al. } \\
2006\end{array}$ \\
\hline Eastern Wood Breeding Bird Data & $\begin{array}{l}\text { http://onlinelibrary.wiley.com/doi/10.1002/97804 } \\
\text { 70999592.app2/summary }\end{array}$ & Terrestrial & Bird & 1 & 29 & 45 & $\mathrm{~N}$ & $\begin{array}{l}\text { Gaston et al. } \\
2000\end{array}$ \\
\hline $\begin{array}{l}\text { El Verde Grid long-term } \\
\text { invertebrate data }\end{array}$ & http://luq2.lternet.edu/data/luqmetadata107 & Terrestrial & Invertebrate & 33 & 22 & 19 & $\mathrm{Y}$ & $\begin{array}{l}\text { Willig et } \\
\text { al.2007 }\end{array}$ \\
\hline
\end{tabular}




\begin{tabular}{|c|c|c|c|c|c|c|c|c|}
\hline Farne Island birds & http://www.jstor.org/stable/1744518 & Terrestrial & Bird & 1 & 29 & 16 & $\mathrm{~N}$ & $\begin{array}{l}\text { Diamond and } \\
\text { May } 1977\end{array}$ \\
\hline $\begin{array}{l}\text { Fish populations on selected } \\
\text { watersheds at Konza Prairie }\end{array}$ & $\begin{array}{l}\text { http://lter.konza.ksu.edu/content/cfp01-fish- } \\
\text { population-selected-watersheds-konza-prairie }\end{array}$ & Freshwater & Fish & 1 & 7 & 17 & $\mathrm{Y}$ & $\begin{array}{l}\text { Whitney et al. } \\
2015\end{array}$ \\
\hline $\begin{array}{l}\text { Fourteen years of mapped, } \\
\text { permanent quadrats in a northern } \\
\text { mixed prairie, USA }\end{array}$ & $\begin{array}{l}\text { http://esapubs.org/archive/ecol/E092/143/metadat } \\
\text { a.htm }\end{array}$ & Terrestrial & Plant & 1 & 7 & 52 & $\mathrm{Y}$ & $\begin{array}{l}\text { Anderson et al. } \\
2011\end{array}$ \\
\hline Hinkley Point fish & $\begin{array}{l}\text { http://www.nature.com/nature/journal/v422/n6933 } \\
\text { /full/nature01547.html }\end{array}$ & Marine & Fish & 1 & 21 & 80 & $\mathrm{~N}$ & $\begin{array}{l}\text { Magurran and } \\
\text { Henderson } \\
2003\end{array}$ \\
\hline Hubbard Brook LTER birds & $\begin{array}{l}\text { https://portal.lternet.edu/nis/mapbrowse?packagei } \\
\text { d=knb-lter-hbr.81.5 }\end{array}$ & Terrestrial & Bird & 4 & 14 & 37 & $\mathrm{~N}$ & Holmes 2016 \\
\hline Indiana stream fish assemblage & http://www.jstor.org/stable/2461070 & Freshwater & Fish & 1 & 12 & 49 & $\mathrm{~N}$ & $\begin{array}{l}\text { Grossman et al. } \\
1982\end{array}$ \\
\hline $\begin{array}{l}\text { Insect Populations via Sticky } \\
\text { Traps at KBS-LTER }\end{array}$ & http://lter.kbs.msu.edu/datatables/67 & Terrestrial & Invertebrate & 10 & 23 & 20 & $\mathrm{Y}$ & $\begin{array}{l}\text { Landis and } \\
\text { Gage } 2015\end{array}$ \\
\hline Ireland amphipods & $\begin{array}{l}\text { http://www.sciencedirect.com/science/article/pii/0 } \\
022098196000305\end{array}$ & Marine & Invertebrate & 1 & $12 *$ & 27 & $\mathrm{~N}$ & $\begin{array}{l}\text { Costello and } \\
\text { Myers } 1996\end{array}$ \\
\hline
\end{tabular}




\begin{tabular}{|c|c|c|c|c|c|c|c|c|}
\hline $\begin{array}{l}\text { Konza LTER grasshopper } \\
\text { monitoring }\end{array}$ & $\begin{array}{l}\text { http://lter.konza.ksu.edu/content/cgr02-sweep- } \\
\text { sampling-grasshoppers-konza-prairie-lter- } \\
\text { watersheds-1982-present }\end{array}$ & Terrestrial & Invertebrate & 16 & 24 & 37 & $\mathrm{Y}$ & $\begin{array}{l}\text { Rode et al. } \\
2017\end{array}$ \\
\hline Konza LTER small mammals & $\begin{array}{l}\text { http://lter.konza.ksu.edu/content/csm01-seasonal- } \\
\text { summary-numbers-small-mammals-14-lter- } \\
\text { traplines-prairie-habitats-konza }\end{array}$ & Terrestrial & Mammal & 14 & 33 & 15 & $\mathrm{Y}$ & $\begin{array}{l}\text { Ricketts and } \\
\text { Sandercock } \\
2016\end{array}$ \\
\hline Lac Croche understory vegetation & $\begin{array}{l}\text { http://www.esapubs.org/archive/ecol/E088/197/de } \\
\text { fault.htm }\end{array}$ & Terrestrial & Plant & 43 & 8 & 83 & $\mathrm{Y}$ & $\begin{array}{l}\text { Paquette et al. } \\
2007\end{array}$ \\
\hline $\begin{array}{l}\text { Yanliao Bay, Taiwan, } \\
\text { Ichthyoplankton }\end{array}$ & NA & Marine & Plankton & 3 & 6 & 137 & $\mathrm{~N}$ & $\begin{array}{l}\text { Hsieh } \\
\text { unpublished }\end{array}$ \\
\hline $\begin{array}{l}\text { Lake Kasumigaura database, } \\
\text { Table } 10 \text { Phytoplankton density }\end{array}$ & $\begin{array}{l}\text { http://db.cger.nies.go.jp/gem/moni- } \\
\text { e/inter/GEMS/database/kasumi/contents/datalist.ht } \\
\text { ml }\end{array}$ & Freshwater & Plankton & 2 & 33 & 172 & $\mathrm{~N}$ & $\begin{array}{l}\text { Takamura and } \\
\text { Nakagawa } \\
2012\end{array}$ \\
\hline $\begin{array}{l}\text { Lake Kasumigaura database, } \\
\text { Table 12-1 Density of Rotifer, } \\
\text { Cladocera and Copepoda }\end{array}$ & $\begin{array}{l}\text { http://db.cger.nies.go.jp/gem/moni- } \\
\text { e/inter/GEMS/database/kasumi/contents/datalist.ht } \\
\text { ml }\end{array}$ & Freshwater & Plankton & 2 & 21 & 62 & $\mathrm{~N}$ & $\begin{array}{l}\text { Takamura et al. } \\
2015\end{array}$ \\
\hline
\end{tabular}




\begin{tabular}{|c|c|c|c|c|c|c|c|c|}
\hline $\begin{array}{l}\text { Lake Kasumigaura database, } \\
\text { Table 14-1 Benthos data }\end{array}$ & $\begin{array}{l}\text { http://db.cger.nies.go.jp/gem/moni- } \\
\text { e/inter/GEMS/database/kasumi/contents/datalist.ht } \\
\mathrm{ml}\end{array}$ & Freshwater & Benthos & 4 & 22 & 10 & $\mathrm{~N}$ & $\begin{array}{l}\text { Iwakuma and } \\
\text { Ueno } 2010\end{array}$ \\
\hline $\begin{array}{l}\text { Lake Kasumigaura database, } \\
\text { Table 15-2 Fish density data }\end{array}$ & $\begin{array}{l}\text { http://db.cger.nies.go.jp/gem/moni- } \\
\text { e/inter/GEMS/database/kasumi/contents/datalist.ht } \\
\text { ml }\end{array}$ & Freshwater & Fish & 1 & 9 & 45 & $\mathrm{~N}$ & $\begin{array}{l}\text { Matsuzaki and } \\
\text { Nohara } 2017\end{array}$ \\
\hline $\begin{array}{l}\text { Long-Term Community } \\
\text { Dynamics of Small Landbirds } \\
\text { with and Without Exposure to } \\
\text { Extensive Disturbance from } \\
\text { Military Training Activities - } \\
\text { Konza prairie site }\end{array}$ & $\begin{array}{l}\text { http://link.springer.com/article/10.1007\%2Fs0026 } \\
\text { 7-009-9421-6 }\end{array}$ & Terrestrial & Bird & 1 & 11 & 62 & $\mathrm{~N}$ & $\begin{array}{l}\text { Rivers et al. } \\
2010\end{array}$ \\
\hline $\begin{array}{l}\text { Long-term dynamics of breeding } \\
\text { birds in broad-leaved deciduous } \\
\text { forest on Hanikatsi Island in the } \\
\text { West-Estonian archipelago }\end{array}$ & $\begin{array}{l}\text { https://www.researchgate.net/publication/2537045 } \\
\text { 70_Long- } \\
\text { term_dynamics_of_breeding_birds_in_broad- } \\
\text { leaved_deciduous_forest_on_Hanikatsi_Island_in } \\
\text { _the_West-Estonian_archipelago }\end{array}$ & Terrestrial & Bird & 1 & 27 & 33 & $\mathrm{~N}$ & $\begin{array}{l}\text { Leito et al. } \\
2006\end{array}$ \\
\hline
\end{tabular}




\begin{tabular}{|c|c|c|c|c|c|c|c|c|}
\hline $\begin{array}{l}\text { Long-term mapped quadrats from } \\
\text { Kansas prairie: demographic } \\
\text { information for herbaceous plants }\end{array}$ & http://esapubs.org/archive/ecol/E088/161/ & Terrestrial & Plant & 51 & 41 & 137 & $\mathrm{Y}$ & $\begin{array}{l}\text { Adler et al. } \\
2007\end{array}$ \\
\hline $\begin{array}{l}\text { Long-term monitoring of } \\
\text { mammals in the face of biotic and } \\
\text { abiotic influences at a semiarid } \\
\text { site in north-central Chile: shrubs } \\
\text { and herbaceous plants }\end{array}$ & $\begin{array}{l}\text { http://esapubs.org/archive/ecol/E094/084/metadat } \\
\text { a.php }\end{array}$ & Terrestrial & Plant & 16 & 16 & 85 & $\mathrm{~N}$ & Kelt et al. 2013 \\
\hline $\begin{array}{l}\text { Long-term monitoring of } \\
\text { Mammals in the face of biotic and } \\
\text { abiotic influences at a semiarid } \\
\text { site in north-central Chile: } \\
\text { mammals }\end{array}$ & $\begin{array}{l}\text { http://esapubs.org/archive/ecol/E094/084/metadat } \\
\text { a.php }\end{array}$ & Terrestrial & Mammal & 4 & 12 & 12 & $\mathrm{Y}$ & Kelt et al. 2013 \\
\hline
\end{tabular}




\begin{tabular}{|c|c|c|c|c|c|c|c|c|}
\hline $\begin{array}{l}\text { Long-Term Nitrogen Deposition: } \\
\text { Population, Community, and } \\
\text { Ecosystem Consequences - } \\
\text { Experiment } 001\end{array}$ & $\begin{array}{l}\text { https://www.cedarcreek.umn.edu/research/data/dat } \\
\text { aset?ple001 }\end{array}$ & Terrestrial & Plant & 3 & 30 & 148 & $\mathrm{Y}$ & Tilman 2012 \\
\hline $\begin{array}{l}\text { Long-term stem inventory data } \\
\text { from tropical rain forest plots in } \\
\text { Australia: trees }>10 \mathrm{~cm} \mathrm{dbh}\end{array}$ & http://esapubs.org/archive/ecol/E095/209/ & Terrestrial & Plant & 20 & 34 & 488 & $\mathrm{Y}$ & $\begin{array}{l}\text { Bradford et al. } \\
2014\end{array}$ \\
\hline Luquillo LTER bird point counts & http://luq.lternet.edu/data/luqmetadata23 & Terrestrial & Bird & 1 & 19 & 39 & $\mathrm{Y}$ & $\begin{array}{l}\text { Willig et } \\
\text { al.2007 }\end{array}$ \\
\hline $\begin{array}{l}\text { Mapped quadrats in sagebrush } \\
\text { steppe: long-term data for } \\
\text { analyzing demographic rates and } \\
\text { plant-plant interactions }\end{array}$ & $\begin{array}{l}\text { http://onlinelibrary.wiley.com/doi/10.1890/10- } \\
\text { 0404.1/abstract }\end{array}$ & Terrestrial & Plant & 1 & 17 & 18 & $\mathrm{Y}$ & $\begin{array}{l}\text { Zachmann et } \\
\text { al. } 2016\end{array}$ \\
\hline $\begin{array}{l}\text { Maryland Biological Stream } \\
\text { Survey Fish Data }\end{array}$ & $\begin{array}{l}\text { http://dnr2.maryland.gov/streams/Pages/mbss.asp } \\
\mathrm{x}\end{array}$ & Freshwater & Fish & 48 & 17 & 86 & $\mathrm{Y}$ & $\begin{array}{l}\text { Roth et al. } \\
2005\end{array}$ \\
\hline
\end{tabular}




\begin{tabular}{|c|c|c|c|c|c|c|c|c|}
\hline $\begin{array}{l}\text { Maryland Biological Stream } \\
\text { Survey Macroinvertebrate Data }\end{array}$ & $\begin{array}{l}\text { http://dnr2.maryland.gov/streams/Pages/mbss.asp } \\
\text { x }\end{array}$ & Freshwater & Benthos & 52 & 17 & 364 & $\mathrm{Y}$ & $\begin{array}{l}\text { Roth et al. } \\
2005\end{array}$ \\
\hline Mediterranean tintinnid ciliates & $\begin{array}{l}\text { http://onlinelibrary.wiley.com/doi/10.1111/j.1365- } \\
\text { 2699.2008.02046.x/abstract }\end{array}$ & Marine & Plankton & 1 & $18^{*}$ & 49 & $\mathrm{~N}$ & $\begin{array}{l}\text { Dolan et al. } \\
2009\end{array}$ \\
\hline $\begin{array}{l}\text { Monitoring the Abundance of } \\
\text { Butterflies 1976-1985 }\end{array}$ & http://jncc.defra.gov.uk/page-2614 & Terrestrial & Invertebrate & 35 & 10 & 44 & $\mathrm{~N}$ & $\begin{array}{l}\text { Pollard et al. } \\
1986\end{array}$ \\
\hline $\begin{array}{l}\text { Mosquitoes of North America } \\
\text { with emphasis in the midwestern } \\
\text { United States: long-term } \\
\text { occurrence patterns }\end{array}$ & http://esapubs.org/archive/ecol/E094/126/ & Terrestrial & Invertebrate & 13 & 37 & 28 & $\mathrm{~N}$ & $\begin{array}{l}\text { Hellmann et al. } \\
2013\end{array}$ \\
\hline Mountain Birdwatch & $\begin{array}{l}\text { https://knb.ecoinformatics.org/\#view/doi:10.5063/ } \\
\text { F1DN430G }\end{array}$ & Terrestrial & Bird & 35 & 11 & 72 & $\mathrm{~N}$ & $\begin{array}{l}\text { Lambert and } \\
\text { Hart } 2015\end{array}$ \\
\hline $\begin{array}{l}\text { North American Breeding Bird } \\
\text { Survey }\end{array}$ & https://www.pwrc.usgs.gov/bbs/ & Terrestrial & Bird & $1000+$ & 15 & 405 & $\mathrm{Y}$ & $\begin{array}{l}\text { Pardieck et al. } \\
2016\end{array}$ \\
\hline
\end{tabular}




\begin{tabular}{|c|c|c|c|c|c|c|c|c|}
\hline $\begin{array}{l}\text { North Temperate Lakes LTER: } \\
\text { Fish Abundance 1981-current, } \\
\text { ELECTRO FISH }\end{array}$ & $\begin{array}{l}\text { https://portal.lternet.edu/nis/mapbrowse?packagei } \\
\text { d=knb-lter-ntl.7.10 }\end{array}$ & Freshwater & Fish & 8 & 21 & 61 & $\mathrm{~N}$ & $\begin{array}{l}\text { De Stasio et al. } \\
1996\end{array}$ \\
\hline $\begin{array}{l}\text { North Temperate Lakes LTER: } \\
\text { Fish Abundance 1981-current, } \\
\text { FYKE NET }\end{array}$ & $\begin{array}{l}\text { https://portal.lternet.edu/nis/mapbrowse?packagei } \\
\text { d=knb-lter-ntl.7.10 }\end{array}$ & Freshwater & Fish & 9 & 31 & 53 & $\mathrm{~N}$ & $\begin{array}{l}\text { De Stasio et al. } \\
1996\end{array}$ \\
\hline $\begin{array}{l}\text { North Temperate Lakes LTER: } \\
\text { Fish Abundance 1981-current, } \\
\text { SEINE }\end{array}$ & $\begin{array}{l}\text { https://portal.lternet.edu/nis/mapbrowse?packagei } \\
\text { d=knb-lter-ntl.7.10 }\end{array}$ & Freshwater & Fish & 9 & 15 & 57 & $\mathrm{~N}$ & $\begin{array}{l}\text { De Stasio et al. } \\
1996\end{array}$ \\
\hline $\begin{array}{l}\text { North Temperate Lakes LTER: } \\
\text { Macrophyte Species at Quadrat } \\
\text { Level - Trout Lake } 1993 \text { - current }\end{array}$ & $\begin{array}{l}\text { https://lter.limnology.wisc.edu/dataset/north- } \\
\text { temperate-lakes-lter-macrophyte-species-quadrat- } \\
\text { level-trout-lake-1993-current }\end{array}$ & Freshwater & Plant & 2 & 20 & 28 & $\mathrm{Y}$ & $\begin{array}{l}\text { Magnuson et } \\
\text { al. } 2010\end{array}$ \\
\hline $\begin{array}{l}\text { North Temperate Lakes LTER: } \\
\text { Macrophyte Transects - Trout } \\
\text { Lake } 1982 \text { - current }\end{array}$ & $\begin{array}{l}\text { https://lter.limnology.wisc.edu/dataset/north- } \\
\text { temperate-lakes-lter-macrophyte-transects-trout- } \\
\text { lake-1982-current }\end{array}$ & Freshwater & Plant & 2 & 22 & 29 & $\mathrm{Y}$ & $\begin{array}{l}\text { Magnuson et } \\
\text { al. } 2010\end{array}$ \\
\hline $\begin{array}{l}\text { North Temperate Lakes LTER: } \\
\text { Phytoplankton - Madison Lakes } \\
\text { Area } 1995 \text { - current }\end{array}$ & $\begin{array}{l}\text { https://lter.limnology.wisc.edu/dataset/north- } \\
\text { temperate-lakes-lter-phytoplankton-madison- } \\
\text { lakes-area-1995-current }\end{array}$ & Freshwater & Plankton & 2 & 18 & 315 & $\mathrm{Y}$ & $\begin{array}{l}\text { Magnuson et } \\
\text { al. } 2011\end{array}$ \\
\hline
\end{tabular}




\begin{tabular}{|c|c|c|c|c|c|c|c|c|}
\hline $\begin{array}{l}\text { North Temperate Lakes LTER: } \\
\text { Phytoplankton - Trout Lake Area } \\
1984 \text { - current }\end{array}$ & $\begin{array}{l}\text { https://lter.limnology.wisc.edu/dataset/north- } \\
\text { temperate-lakes-lter-phytoplankton-trout-lake- } \\
\text { area-1984-current }\end{array}$ & Freshwater & Plankton & 2 & 10 & 135 & $\mathrm{~N}$ & $\begin{array}{l}\text { Magnuson et } \\
\text { al. } 2007\end{array}$ \\
\hline $\begin{array}{l}\text { North Temperate Lakes LTER: } \\
\text { Zooplankton - Madison Lakes } \\
\text { Area } 1997 \text { - current }\end{array}$ & $\begin{array}{l}\text { https://lter.limnology.wisc.edu/dataset/north- } \\
\text { temperate-lakes-lter-zooplankton-madison-lakes- } \\
\text { area-1997-current }\end{array}$ & Freshwater & Plankton & 2 & 19 & 26 & $\mathrm{Y}$ & $\begin{array}{l}\text { Magnuson et } \\
\text { al. } 2011\end{array}$ \\
\hline $\begin{array}{l}\text { North Temperate Lakes LTER: } \\
\text { Zooplankton - Trout Lake Area } \\
1982 \text { - current }\end{array}$ & $\begin{array}{l}\text { https://lter.limnology.wisc.edu/dataset/north- } \\
\text { temperate-lakes-lter-zooplankton-trout-lake-area- } \\
\text { 1982-current }\end{array}$ & Freshwater & Plankton & 7 & 29 & 100 & $\mathrm{Y}$ & $\begin{array}{l}\text { Magnuson et } \\
\text { al. } 1983\end{array}$ \\
\hline $\begin{array}{l}\text { One hundred and six years of } \\
\text { population and community } \\
\text { dynamics of Sonoran Desert } \\
\text { Laboratory perennials }\end{array}$ & http://esapubs.org/archive/ecol/E094/083/ & Terrestrial & Plant & 2 & 28 & 58 & $\mathrm{~N}$ & $\begin{array}{l}\text { Rodriguez- } \\
\text { Buritica et al. } \\
2013\end{array}$ \\
\hline $\begin{array}{l}\text { Plant species composition on } \\
\text { selected watersheds at Konza } \\
\text { Prairie }\end{array}$ & $\begin{array}{l}\text { http://lter.konza.ksu.edu/content/pvc02-plant- } \\
\text { species-composition-selected-watersheds-konza- } \\
\text { prairie }\end{array}$ & Terrestrial & Plant & 4 & 18 & 294 & $\mathrm{Y}$ & $\begin{array}{l}\text { Briggs et al. } \\
2002\end{array}$ \\
\hline
\end{tabular}




\begin{tabular}{|c|c|c|c|c|c|c|c|c|}
\hline Portal Plants, summer & $\begin{array}{l}\text { http://esapubs.org/archive/ecol/E090/118/metadat } \\
\text { a.htm }\end{array}$ & Terrestrial & Plant & 24 & 14 & 105 & $\mathrm{Y}$ & $\begin{array}{l}\text { Ernest et al. } \\
2009\end{array}$ \\
\hline Portal Plants, winter & $\begin{array}{l}\text { http://esapubs.org/archive/ecol/E090/118/metadat } \\
\text { a.htm }\end{array}$ & Terrestrial & Plant & 1 & 14 & 95 & $\mathrm{Y}$ & $\begin{array}{l}\text { Ernest et al. } \\
2009\end{array}$ \\
\hline Portal Rodents & $\begin{array}{l}\text { http://esapubs.org/archive/ecol/E090/118/metadat } \\
\text { a.htm }\end{array}$ & Terrestrial & Mammal & 1 & 15 & 21 & $\mathrm{Y}$ & $\begin{array}{l}\text { Ernest et al. } \\
2009\end{array}$ \\
\hline $\begin{array}{l}\text { Powdermill Biological Station } \\
\text { Small Mammal Database }\end{array}$ & $\begin{array}{l}\mathrm{http}: / / \text { ecologicaldata.org/wiki/powdermill- } \\
\text { biological-station-small-mammal-database }\end{array}$ & Terrestrial & Mammal & 1 & 11 & 16 & $\mathrm{~N}$ & Merritt 1999 \\
\hline Preston 1948 moths & https://www.jstor.org/stable/1930989 & Terrestrial & Invertebrate & 2 & 22 & 291 & $\mathrm{~N}$ & Preston 1948 \\
\hline $\begin{array}{l}\text { SBC LTER: Reef: Kelp Forest } \\
\text { Community Dynamics: Fish } \\
\text { abundance }\end{array}$ & $\begin{array}{l}\text { https://portal.lternet.edu/nis/mapbrowse?packagei } \\
\text { d=knb-lter-sbc. } 17.27\end{array}$ & Marine & Fish & 39 & 13 & 58 & $\mathrm{Y}$ & Reed 2013 \\
\hline
\end{tabular}




\begin{tabular}{|c|c|c|c|c|c|c|c|c|}
\hline Sevilleta LTER arthropods & $\begin{array}{l}\text { https://portal.lternet.edu/nis/mapbrowse?packagei } \\
\text { d=knb-lter-sev.29.175390 }\end{array}$ & Terrestrial & Invertebrate & 42 & 12 & 365 & $\mathrm{Y}$ & Lightfoot 2010 \\
\hline Sevilleta LTER mammals & $\begin{array}{l}\text { http://sev.lternet.edu/content/small-mammal- } \\
\text { exclosure-study-smes-0 }\end{array}$ & Terrestrial & Mammal & 1 & 16 & 24 & $\mathrm{Y}$ & $\begin{array}{l}\text { Baéz et al. } \\
2006\end{array}$ \\
\hline Skokholm birds & $\begin{array}{l}\text { http://ecologicaldata.org/wiki/skokholm-bird- } \\
\text { observatory }\end{array}$ & Terrestrial & Bird & 1 & 47 & 29 & $\mathrm{~N}$ & $\begin{array}{l}\text { Williamson } \\
1983\end{array}$ \\
\hline $\begin{array}{l}\text { Small Mammal Exclosure Study } \\
\text { (SMES) Vegetation Data from the } \\
\text { Chihuahuan Desert Grassland and } \\
\text { Shrubland at the Sevilleta } \\
\text { National Wildlife Refuge, New } \\
\text { Mexico (2006-2009) }\end{array}$ & http://repository.unm.edu/handle/1928/29843 & Terrestrial & Plant & 7 & 15 & 101 & $\mathrm{Y}$ & Lightfoot 2010 \\
\hline $\begin{array}{l}\text { Small Mammal Exclosure Study. } \\
\text { Jornada LTER }\end{array}$ & http://jornada.nmsu.edu/lter/project/49356/view & Terrestrial & Mammal & 1 & 7 & 15 & $\mathrm{Y}$ & Lightfoot 1995 \\
\hline
\end{tabular}




\begin{tabular}{|c|c|c|c|c|c|c|c|c|}
\hline $\begin{array}{l}\text { Species composition and } \\
\text { population fluctuations of alpine } \\
\text { bird communities during } 38 \text { years } \\
\text { in the Scandinavian mountain } \\
\text { range }\end{array}$ & $\begin{array}{l}\text { http://portal.research.lu.se/portal/en/publications/s } \\
\text { pecies-composition-and-population-fluctuations- } \\
\text { of-alpine-bird-communities-during-38-years-in- } \\
\text { the-scandinavian-mountain-range(94d93170- } \\
\text { 8b5a-4d80-a72b-c06fd0149dcb).html }\end{array}$ & Terrestrial & Bird & 4 & 38 & 47 & $\mathrm{~N}$ & Svensson 2006 \\
\hline $\begin{array}{l}\text { Species trends, turnover and } \\
\text { composition of a woodland bird } \\
\text { community in southern Sweden } \\
\text { during a period of } 57 \text { years }\end{array}$ & $\begin{array}{l}\text { http://birdlife.se//1020.0.1.0/274/download_24762 } \\
\text {.php }\end{array}$ & Terrestrial & Bird & 1 & 57 & 41 & $\mathrm{~N}$ & $\begin{array}{l}\text { Svensson et al. } \\
2010\end{array}$ \\
\hline $\begin{array}{l}\text { Stream fish assemblage stability } \\
\text { in a southern Appalachian stream } \\
\text { at the Coweeta Hydrologic } \\
\text { Laboratory from } 1984 \text { to } 1995\end{array}$ & $\begin{array}{l}\text { https://portal.lternet.edu/nis/mapbrowse?packagei } \\
\text { d=knb-lter-cwt.3047.13 }\end{array}$ & Freshwater & Fish & 2 & 10 & 14 & $\mathrm{~N}$ & Grossman 2007 \\
\hline $\begin{array}{l}\text { Structure and dynamics of a } \\
\text { passerine bird community in a } \\
\text { spruce-dominated boreal forest }\end{array}$ & $\begin{array}{l}\text { http://www.jstor.org/stable/23735355?seq=1\#page } \\
\text { _scan_tab_contents }\end{array}$ & Terrestrial & Bird & 1 & 12 & 33 & $\mathrm{~N}$ & Hogstad 1993 \\
\hline
\end{tabular}




\begin{tabular}{|c|c|c|c|c|c|c|c|c|}
\hline $\begin{array}{l}\text { Temporal variation in richness } \\
\text { and composition of recruits in a } \\
\text { diverse cnidarian assemblage of } \\
\text { subtropical Brazil }\end{array}$ & $\begin{array}{l}\text { http://www.sciencedirect.com/science/article/pii/S } \\
0022098114001877\end{array}$ & Marine & Invertebrate & 1 & 8 & 34 & $\mathrm{~N}$ & $\begin{array}{l}\text { Fernandez et } \\
\text { al. } 2014\end{array}$ \\
\hline $\begin{array}{l}\text { The 37-year dynamics of a } \\
\text { subalpine passerine bird } \\
\text { community, with special } \\
\text { emphasis on the influence of } \\
\text { environmental temperature and } \\
\text { Epirrita autumnata cycles }\end{array}$ & $\begin{array}{l}\text { http://birdlife.se//1020.0.1.0/40/download_18564. } \\
\text { php }\end{array}$ & Terrestrial & Bird & 1 & 37 & 35 & $\mathrm{~N}$ & $\begin{array}{l}\text { Enemar et al. } \\
2004\end{array}$ \\
\hline $\begin{array}{l}\text { Vegetation surveys in large- } \\
\text { herbivore exclusion in an African } \\
\text { savanna: five years of the } \\
\text { UHURU experiment }\end{array}$ & $\begin{array}{l}\text { http://www.esapubs.org/archive/ecol/E095/064/m } \\
\text { etadata.php }\end{array}$ & Terrestrial & Plant & 7 & 6 & 90 & $\mathrm{Y}$ & $\begin{array}{l}\text { Kartzinel et al. } \\
2014\end{array}$ \\
\hline $\begin{array}{l}\text { Weekly record of bird species } \\
\text { observed on Konza Prairie }\end{array}$ & $\begin{array}{l}\text { http://lter.konza.ksu.edu/content/cbp01-variable- } \\
\text { distance-line-transect-sampling-bird-population- } \\
\text { numbers-different-habitats }\end{array}$ & Terrestrial & Bird & 16 & 26 & 221 & $\mathrm{Y}$ & $\begin{array}{l}\text { Verheijen et al. } \\
2017\end{array}$ \\
\hline $\begin{array}{l}\text { Western English Channel } \\
\text { phytoplankton }\end{array}$ & $\begin{array}{l}\text { http://plankt.oxfordjournals.org/content/32/5/643.f } \\
\text { ull\#sec-5 }\end{array}$ & Marine & Plankton & 1 & 18 & 157 & $\mathrm{~N}$ & $\begin{array}{l}\text { Widdicombe et } \\
\text { al. } 2010\end{array}$ \\
\hline
\end{tabular}




\begin{tabular}{|l|l|l|l|l|l|l|l|l|}
\hline Zooplankton survey of Oneida & https://knb.ecoinformatics.org/\#view/kgordon.17. & Freshwater & Plankton & 5 & 37 & 30 & Y Rudstam 2008 \\
Lake & 56 & & & & & & \\
\hline
\end{tabular}




\section{Data Citations}

Adler, P. B., W. R. Tyburczy, and W. K. Lauenroth. 2007. Ecological Archives E088-161. Longterm mapped quadrats from Kansas prairie: demographic information for herbaceaous plants.

Anderson, J., L. Vermeire, and P. B. Adler. 2011. Fourteen years of mapped, permanent quadrats in a northern mixed prairie, USA. Ecology 92:1703-1703.

Báez, S., S. L. Collins, D. Lightfoot, and T. L. Koontz. 2006. Bottom-up Regulation of Plant Community Structure in an Aridland Ecosystem. Ecology 87:2746-2754.

Bradford, M. G., H. T. Murphy, A. J. Ford, D. L. Hogan, and D. J. Metcalfe. 2014. Long-term stem inventory data from tropical rain forest plots in Australia. Ecology 95:2362-2362.

Briggs, J. M., A. K. Knapp, and B. L. Brock. 2002. Expansion of Woody Plants in Tallgrass Prairie: A Fifteen-year Study of Fire and Fire-grazing Interactions. The American Midland Naturalist 147:287-294.

Costello, M. J., and A. A. Myers. 1996. Turnover of transient species as a contributor to the richness of a stable amphipod (Crustacea) fauna in a sea inlet. Journal of Experimental Marine Biology and Ecology, Marine Biodiversity 202:49-62.

Coweeta Long Term Ecological Research Program, and G. D. Grossman. 2007. Stream fish assemblage stability in a southern Appalachian stream at the Coweeta Hydrologic Laboratory from 1984 to 1995. Long Term Ecological Research Network.

Diamond, J. M., and R. M. May. 1977. Species Turnover Rates on Islands: Dependence on Census Interval. Science 197:266-270. 
Dolan, J. R., M. E. Ritchie, A. Tunin-Ley, and M.-D. Pizay. 2009. Dynamics of core and occasional species in the marine plankton: tintinnid ciliates in the north-west Mediterranean Sea. Journal of Biogeography 36:887-895.

Enemar, A., B. Sjöstrand, G. Andersson, and T. Von Proschwitz. 2004. The 37-year dynamics of a subalpine passerine bird community, with special emphasis on the influence of environmental temperature and Epirrita autumnata cycles. Ornis Svecica 14:63-106.

Ernest, S. K. M., T. J. Valone, and J. H. Brown. 2009. Long-term monitoring and experimental manipulation of a Chihuahuan Desert ecosystem near Portal, Arizona, USA. Ecology 90:1708-1708.

Fernandez, M. O., S. A. Navarrete, and A. C. Marques. 2014. Temporal variation in richness and composition of recruits in a diverse cnidarian assemblage of subtropical Brazil. Journal of Experimental Marine Biology and Ecology 460:144-152.

Gaston, K. J., and T. M. Blackburn, eds. 2000. Appendix II: Eastern Wood Breeding Bird Data. Pages 355-357 in Pattern and Process in Macroecology. Blackwell Science Ltd.

Grossman, G. D., P. B. Moyle, and J. O. Whitaker. 1982. Stochasticity in Structural and Functional Characteristics of an Indiana Stream Fish Assemblage: A Test of Community Theory. The American Naturalist 120:423-454.

Hall, G. A. 1984. A Long-Term Bird Population Study in an Appalachian Spruce Forest. The Wilson Bulletin 96:228-240.

Hellmann, J. J., J. D. K. Dzurisin, T. Wright, D. Cieslak, S. Pecoraro, K. E. Smith, K. Hayhoe, et al. 2013. Mosquitoes of North America with emphasis in the midwestern United States: long-term occurrence patterns. Ecology 94:1433-1433. 
Hogstad, O. 1993. Structure and dynamics of a passerine bird community in a spruce-dominated boreal forest. A 12-year study. Annales Zoologici Fennici 30:43-54.

Holmes, R. T. 2016. Bird Abundances at the Hubbard Brook Experimental Forest (1969-present) and on three replicate plots (1986-2000) in the White Mountain National Forest. Long Term Ecological Research Network.

How, R. A. 1998. Long-term sampling of a herpetofaunal assemblage on an isolated urban bushland remnant, Bold Park, Perth. Journal of the Royal Society of Western Australia $81: 143-148$.

Iwakuma, T., and R. Ueno. 2010. III. Biological Data 14. Zoobenthos. Lake Kasumigaura DataBase.

Kartzinel, T. R., J. R. Goheen, G. K. Charles, E. DeFranco, J. E. Maclean, T. O. Otieno, T. M. Palmer, et al. 2014. Plant and small-mammal responses to large-herbivore exclusion in an African savanna: five years of the UHURU experiment. Ecology 95:787-787.

Kelt, D. A., P. L. Meserve, J. R. Gutiérrez, W. B. Milstead, and M. A. Previtali. 2013. Long-term monitoring of mammals in the face of biotic and abiotic influences at a semiarid site in north-central Chile. Ecology 94:977-977.

Kendeigh, S. C. 1982. Bird populations in east central Illinois : fluctuations, variations, and development over a half-century / 52. Champaign : University of Illinois Press.

Kenner, M. C., J. A. Estes, M. T. Tinker, J. L. Bodkin, R. K. Cowen, C. Harrold, B. B. Hatfield, et al. 2013. A multi-decade time series of kelp forest community structure at San Nicolas Island, California (USA). Ecology 94:2654-2654. 
Kushner, D. J., A. Rassweiler, J. P. McLaughlin, and K. D. Lafferty. 2013. A multi-decade time series of kelp forest community structure at the California Channel Islands. Ecology $94: 2655-2655$.

Lambert, J. D., and J. Hart. 2015. Knowledge Network for Biocomplexity. Vermont Center for Ecostudies, Mountain Birdwatch 1.0.

Landis, D., and S. Gage. 2015. Arthropod diversity and pest suppression in agricultural landscapes. The ecology of agricultural landscapes: long-term research on the path to sustainability. Oxford University Press.

Leito, A., J. Truu, E. Roosaluste, and I. Põder. 2006. Long-term dynamics of breeding birds in broad-leaved deciduous forest on Hanikatsi Island in the West-Estonian archipelago. Ornis Fennica 83.

Lightfoot, D. 1995b. Long-Term and Short-Term Data by Research Area| The Jornada. Small Mammal Exclosure Study.

Lightfoot, D. 2010a. Small Mammal Exclosure Study (SMES) Vegetation Data from the Chihuahuan Desert Grassland and Shrubland at the Sevilleta National Wildlife Refuge, New Mexico (1995-2009). http://dx.doi.org/10.6073/pasta/6c758bc7e6e3ea95242d787ee49a263a.

Lightfoot, D. C., S. L. Brantley, and C. D. Allen. 2008. Geographic Patterns of Ground-dwelling Arthropods Across an Ecoregional Transition in the North American Southwest. Western North American Naturalist 68:83-102.

LTER, S. B. C., and D. C. Reed. 2013. SBC LTER: Reef: Kelp Forest Community Dynamics: Fish abundance. Long Term Ecological Research Network. 
Magnuson, J. J., S. R. Carpenter, and E. H. Stanley. 1983. North Temperate Lakes LTER:

Zooplankton - Trout Lake Area 1982 - current | North Temperate Lakes. North

Temperate Lakes LTER: Zooplankton - Trout Lake Area 1982 - current.

Magnuson, J. J., S. R. Carpenter, and E. H. Stanley. 2007. North Temperate Lakes LTER:

Phytoplankton - Trout Lake Area 1984 - current | North Temperate Lakes. North

Temperate Lakes LTER: Phytoplankton - Trout Lake Area 1984 - current.

Magnuson, J. J., S. R. Carpenter, and E. H. Stanley. 2010a. North Temperate Lakes LTER:

Macrophyte Transects - Trout Lake 1982 - current | North Temperate Lakes. North

Temperate Lakes LTER: Macrophyte Transects - Trout Lake 1982 - current.

Magnuson, J. J., S. R. Carpenter, and E. H. Stanley. 2010b. North Temperate Lakes LTER:

Macrophyte Species at Quadrat Level - Trout Lake 1993 - current | North Temperate

Lakes. North Temperate Lakes LTER: Macrophyte Species at Quadrat Level - Trout

Lake 1993 - current.

Magnuson, J. J., S. R. Carpenter, and E. H. Stanley. 2011. North Temperate Lakes LTER:

Phytoplankton - Madison Lakes Area 1995 - current | North Temperate Lakes. North

Temperate Lakes LTER: Phytoplankton - Madison Lakes Area 1995 - current.

Magurran, A. E., and P. A. Henderson. 2003. Explaining the excess of rare species in natural species abundance distributions. Nature 422:714-716.

Matsuzaki, S., and S. Nohara. n.d. Table 15-1 Fish density data. Table 15-1 Fish density data.

McGlinn, D. J., P. G. Earls, and M. W. Palmer. 2010. A 12-year study on the scaling of vascular plant composition in an Oklahoma tallgrass prairie. Ecology 91:1872-1872.

Merritt, J. 1999. Long Term Mammal Data from Powdermill Biological Station 1979-1999. Long Term Ecological Research Network. 
Lightfoot, D. 2010b. Ground Arthropod Community Survey in Grassland, Shrubland, and Woodland at the Sevilleta National Wildlife Refuge, New Mexico (1992-2004). Long Term Ecological Research Network.

Muldavin, E., and S. Collins. 2016. 2003 Prescribed Burn Effect on Chihuahuan Desert Grasses and Shrubs at the Sevilleta National Wildlife Refuge, New Mexico: Species Composition Study (2004-present) | Sevilleta LTER.

Novak, I. 1983. An efficient light-trap for catching insects. Acta entomologica bohemoslovaca. NTL LTER Lead PI, Center For Limnology, and NTL LTER. 2012. North Temperate Lakes LTER: Fish Abundance 1981 - current.

Paquette, A., E. Laliberté, A. Bouchard, S. de Blois, P. Legendre, and J. Brisson. 2007. Lac Croche Understory Vegetation Data Set (1998-2006). Ecology 88:3209-3209.

Pardieck, K. L., D. J. Ziolkowski Jr., M. Lutmerding, K. Campbell, and M. A. R. Hudson. 2017. BBS - Raw Data - USGS Patuxent Wildlife Research Center. North American Breeding Bird Survey Dataset 1966 - 2016, version 2016.0.

Pollard, E., M. L. Hall, and T. J. Bibby. 1986. Joint Nature Conservation Committee. Monitoring the abundance of butterflies 1976-1985.

Preston, F. W. 1948. The Commonness, And Rarity, of Species. Ecology 29:254-283.

Preston, F.W. 1960. Time and Space and the Variation of Species. Ecology 41:612-627.

Ricketts, A. M., and B. K. Sandercock. 2016. Patch-burn grazing increases habitat heterogeneity and biodiversity of small mammals in managed rangelands. Ecosphere 7:1-16.

Rivers, J. W., P. S. Gipson, D. P. Althoff, and J. S. Pontius. 2010. Long-Term Community Dynamics of Small Landbirds with and Without Exposure to Extensive Disturbance from Military Training Activities. Environmental Management 45:203-216. 
Rode, M., N. P. Lemoine, and M. D. Smith. 2017. Prospective evidence for independent nitrogen and phosphorus limitation of grasshopper (Chorthippus curtipennis) growth in a tallgrass prairie. PLOS ONE 12:e0177754.

Rodriguez-Buritica, S., H. Raichle, R. H. Webb, R. M. Turner, and L. Venable. 2013. One hundred and six years of population and community dynamics of Sonoran Desert Laboratory perennials. Ecology 94:976-976.

Rudstram, L. 2008. Knowledge Network for Biocomplexity. Zooplankton survey of Oneida Lake, New York, 1964 - 2012.

Shaver, G. 2006. Above ground plant biomass in a mesic acidic tussock tundra experimental site from 1982 to 2015 Arctic LTER, Toolik Lake, Alaska. Long Term Ecological Research Network.

Svensson, S. 2006. Species composition and population fluctuations of alpine bird communities during 38 years in the Scandinavian mountain range. Ornis Svecica 16:183-210.

Svensson, S., A. M. Thorner, and N. E. I. Nyholm. 2010. Species trends, turnover and composition of a woodland bird community in southern Sweden during a period of fiftyseven years. Ornis Svecica 20:31-40.

Takamura, N., and M. Nakagawa. n.d. Phytoplankton species abundance in Lake Kasumigaura (Japan) monitored monthly or biweekly since 1978. Ecological Research Data Paper Archives.

Takamura, N., M. Nakagawa, and T. Hanazato. n.d. Metadata - Ecologial Research Data Paper Archives. Ecological Research Data Paper Archives. 
Thorne, J. H., J. O’Brien, M. L. Forister, and A. M. Shapiro. 2006. Building phenological models from presence/absence data for a butterfly fauna. Ecological applications : a publication of the Ecological Society of America.

Tilman, D., P. B. Reich, and F. Isbell. 2012. Biodiversity impacts ecosystem productivity as much as resources, disturbance, or herbivory. Proceedings of the National Academy of Sciences of the United States of America 1-4.

Vanholder, B. 1997. Belgian Migrating Lepidoptera.

Verheijen, B. H. F., D. A. Rintoul, B. K. Sandercock, and B. K. Sandercock. 2017. Habitat guild drives variation in apparent survival of landbirds in the Great Plains. Wilson Journal of Ornithology 129:259-270.

Vickery, W. L., and T. D. Nudds. 1984. Detection of Density-Dependent Effects in Annual Duck Censuses. Ecology 65:96-104.

Wesołowski, T., C. Mitrus, D. Czeszczewik, and P. Rowiński. 2010. Breeding Bird Dynamics in a Primeval Temperate Forest Over Thirty-Five Years: Variation and Stability in the Changing World. Acta Ornithologica 45:209-232.

Whitney, J. E., K. B. Gido, E. C. Martin, and K. J. Hase. 2016. The first to arrive and the last to leave: colonisation and extinction dynamics of common and rare fishes in intermittent prairie streams. Freshwater Biology 61:1321-1334.

Widdicombe, C. E., D. Eloire, D. Harbour, R. P. Harris, and P. J. Somerfield. 2010. Long-term phytoplankton community dynamics in the Western English Channel. Journal of Plankton Research 32:643-655. 
Wilgers, D. J., E. A. Horne, B. K. Sandercock, and A. W. Volkmann. 2006. Effects of rangeland management on community dynamics of the herpetofauna of the tallgrass prairie. Herpetologica 62:378-388.

Williamson, M. 1983. The Land-Bird Community of Skokholm: Ordination and Turnover. Oikos $41: 378-384$.

Willig, M. R. 2007a. Luquillo LTER. El Verde Grid long-term invertebrate data.

Willig, M. R. 2007b. Luquillo LTER. Bird abundance - point counts.

Zachmann, L., C. Moffet, and P. Adler. 2010. Mapped quadrats in sagebrush steppe: long-term data for analyzing demographic rates and plant-plant interactions. Ecology 91:34273427. 


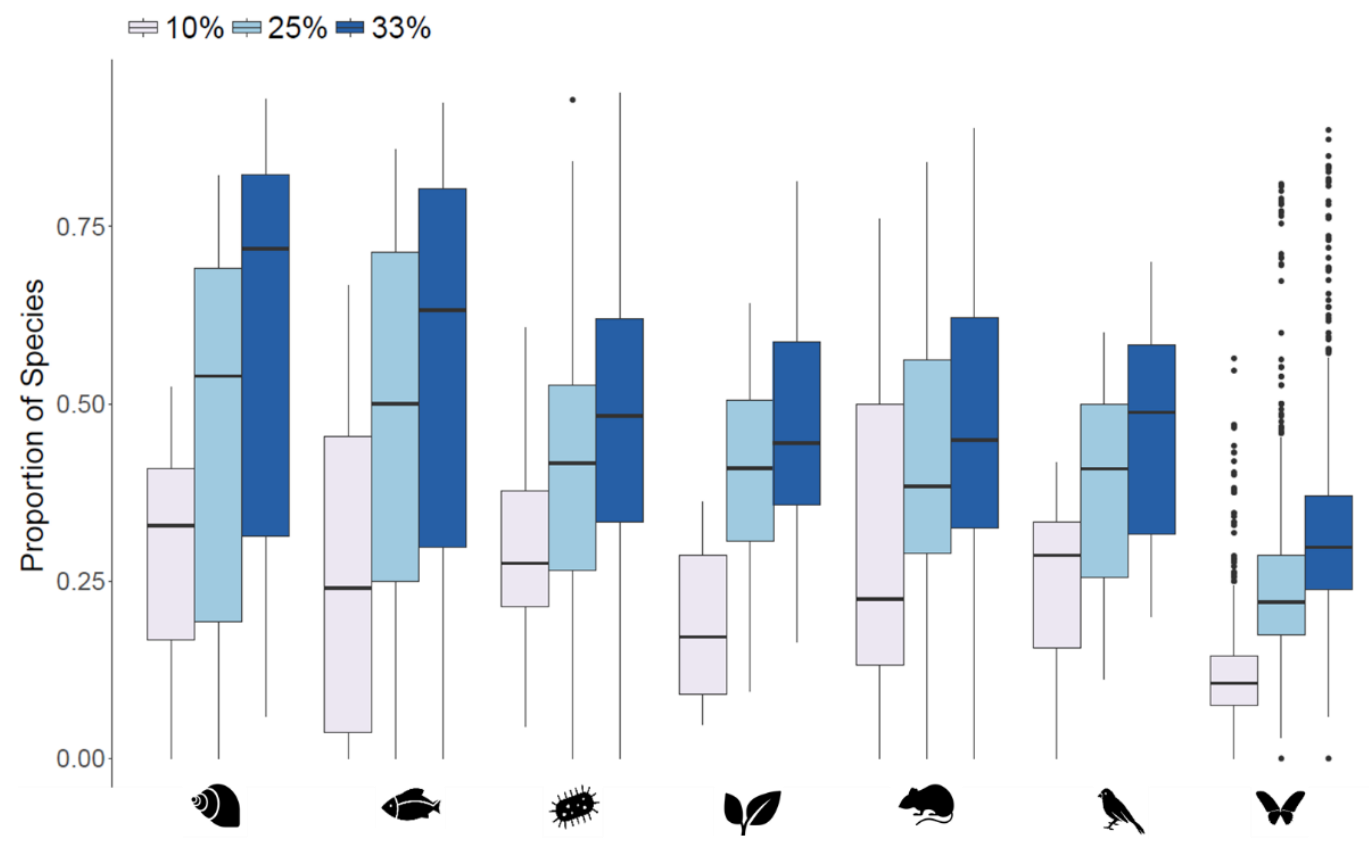

Figure A2. The impact of different thresholds on the proportion of transient species in assemblages from different taxonomic groups. Taxon symbols as in Figure 2. 

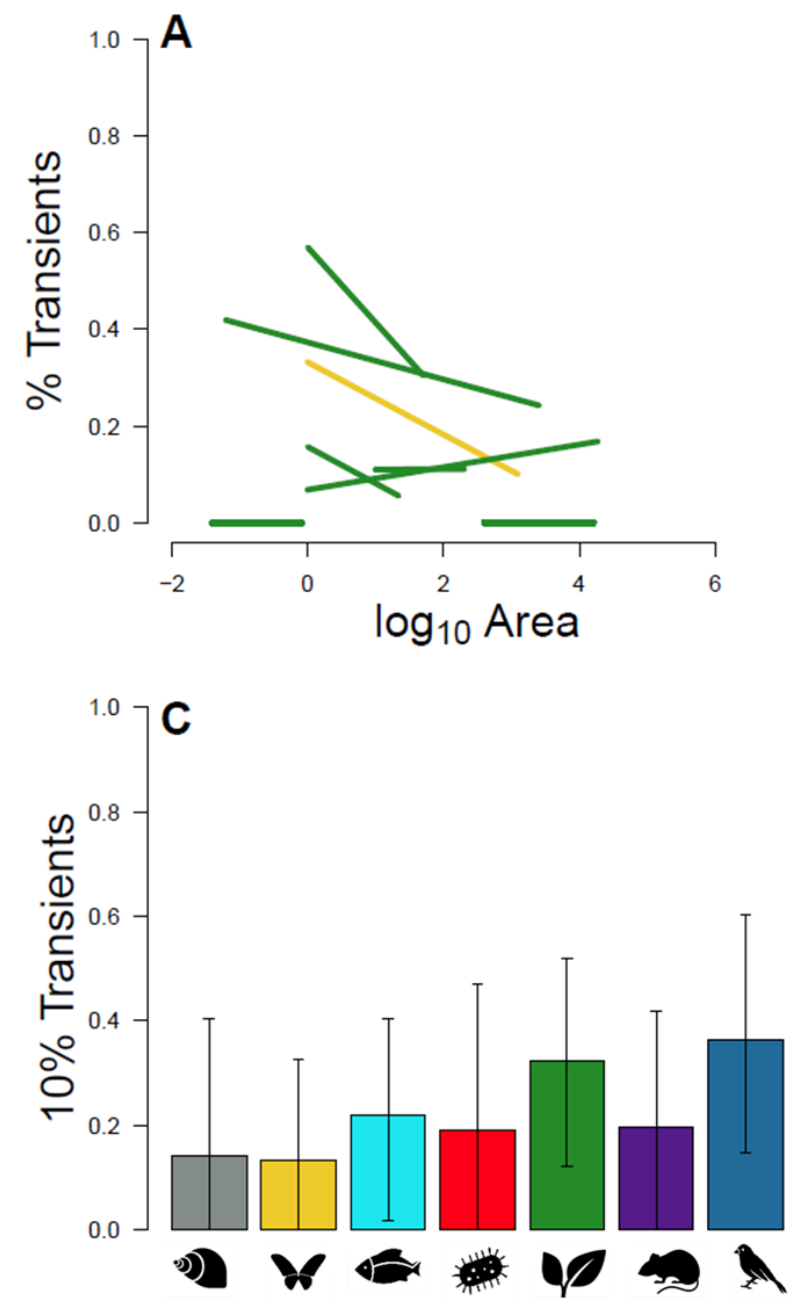
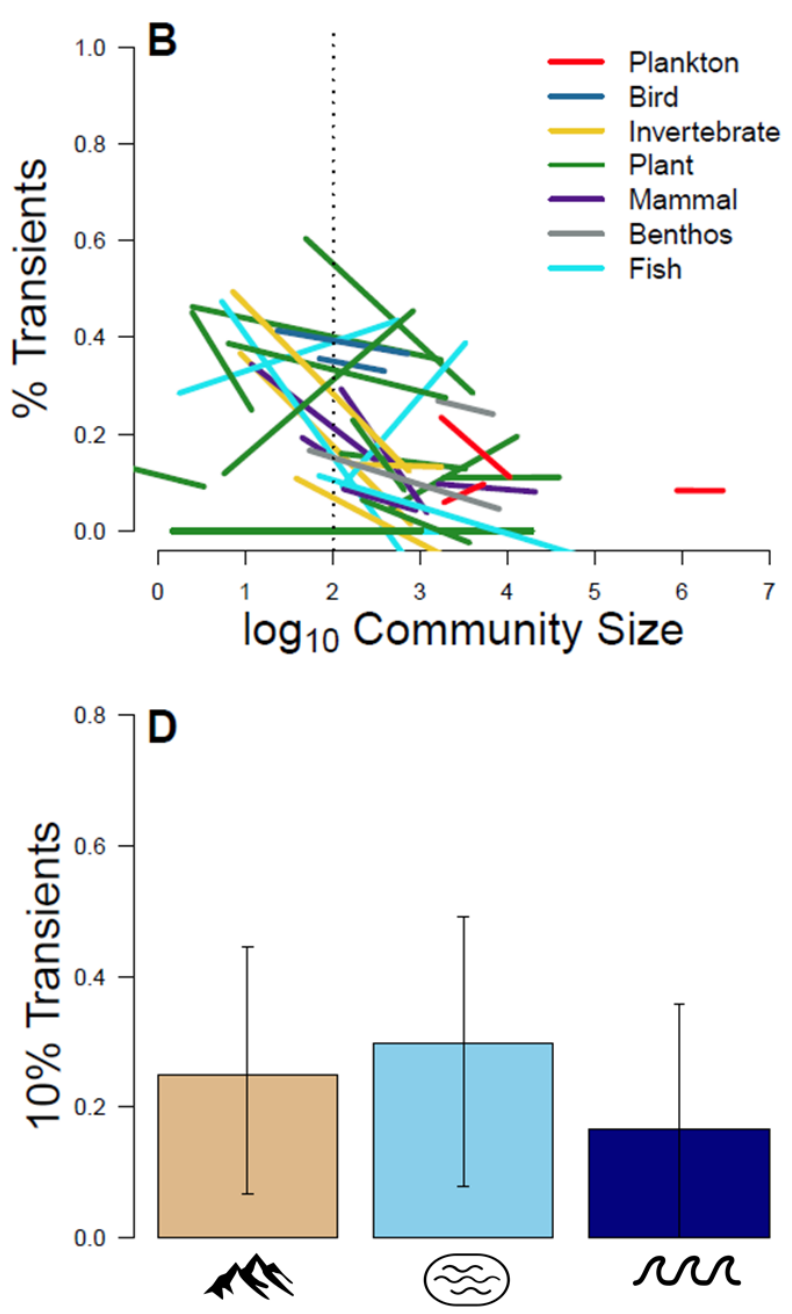

Figure A3. The impact of scale on the proportion of transient species as displayed in Figure 4 in the main text, but where transient species are defined as those with temporal occupancy $\leq 10 \%$. 

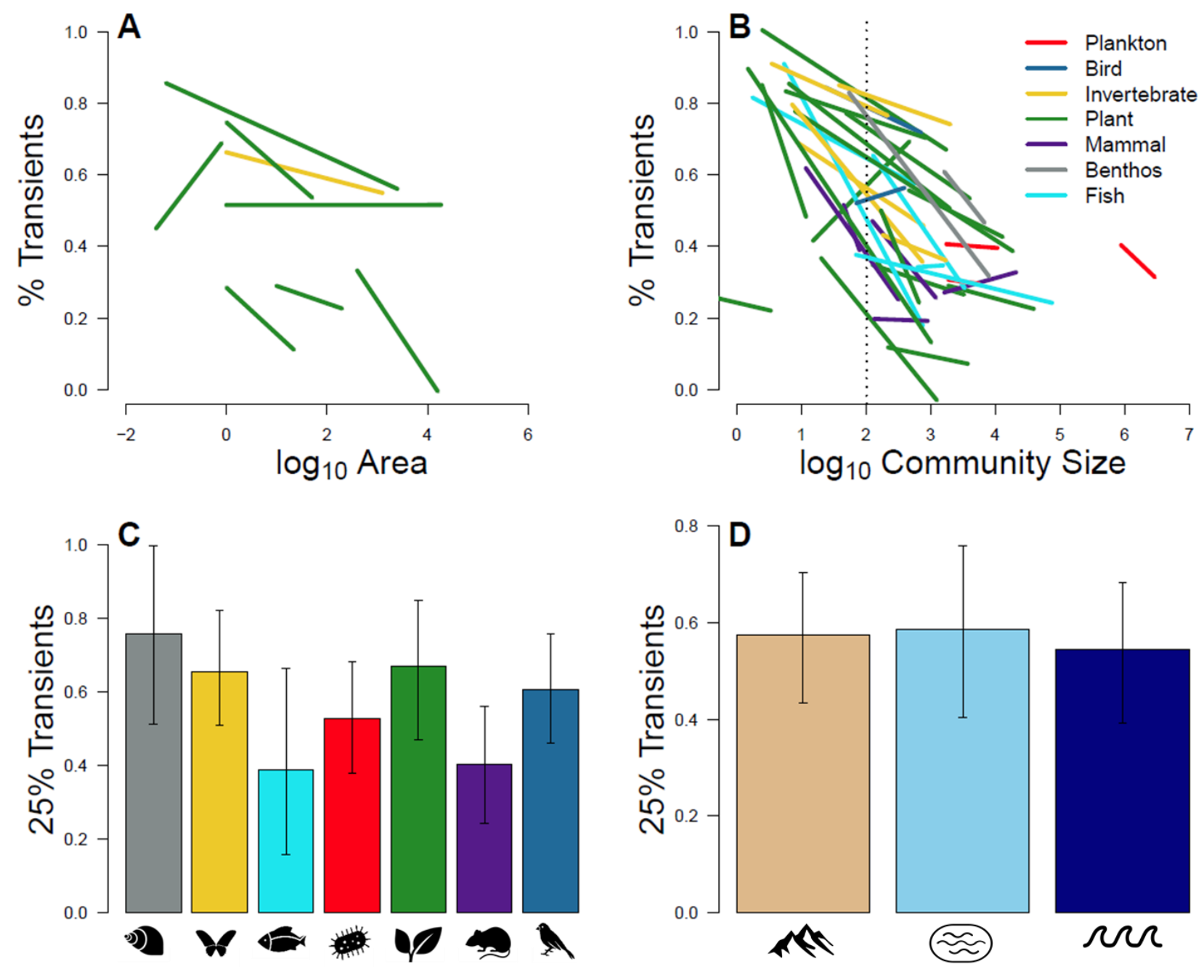

Figure A4. The impact of scale on the proportion of transient species as displayed in Figure 4 in the main text, but where transient species are defined as those with temporal occupancy $\leq 25 \%$. 


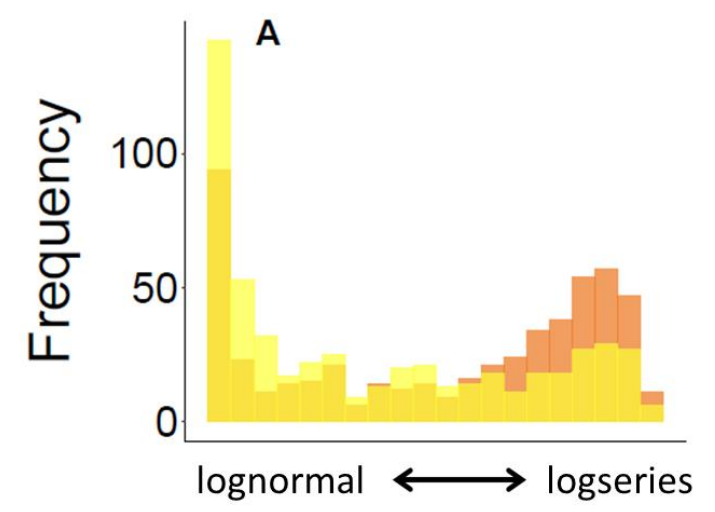

Akaike Weight

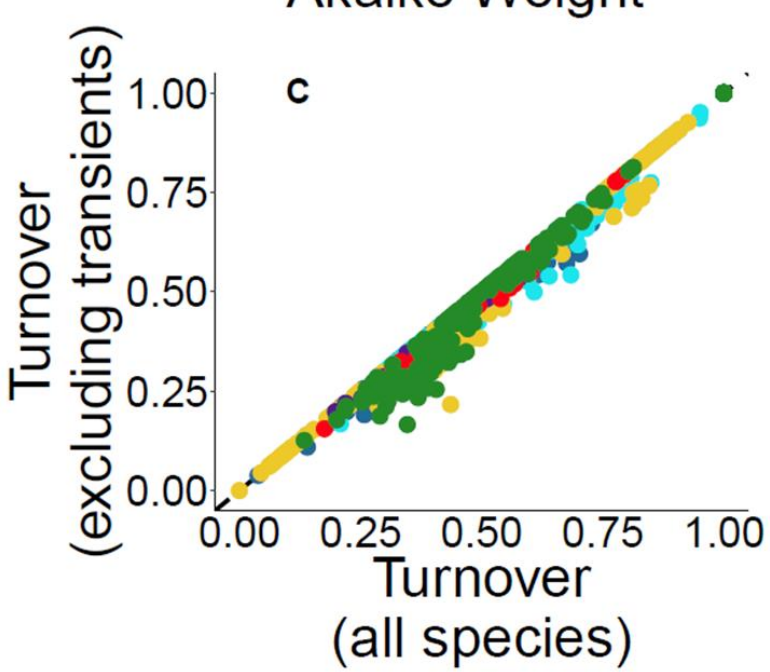

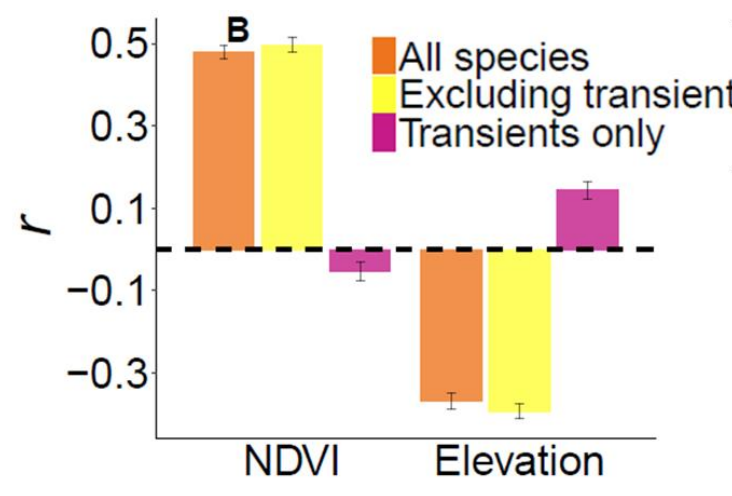

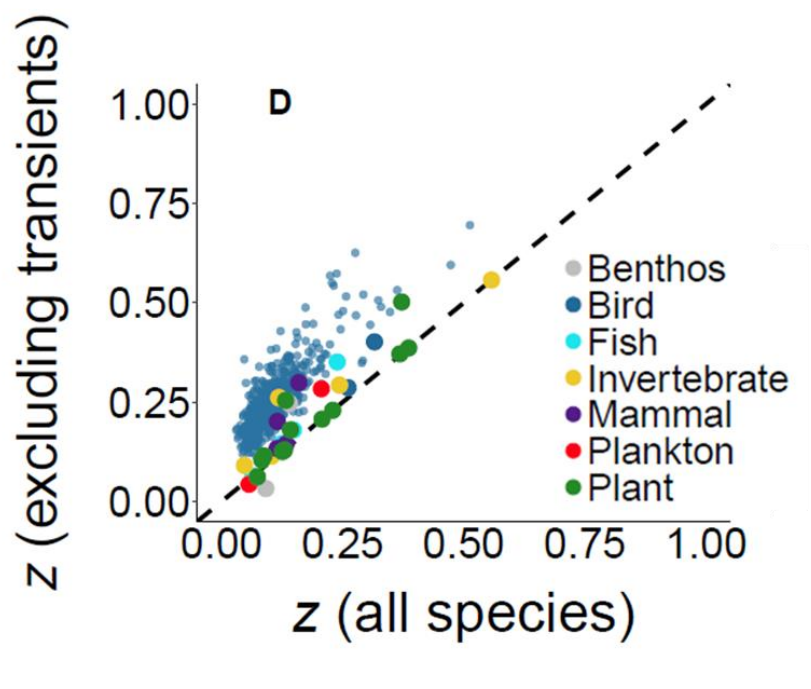

Figure A5. Impact of excluding transient species on four ecological patterns as displayed in Figure 5 in the main text, but where transient species are defined as those with temporal occupancy $\leq$ $10 \%$. 

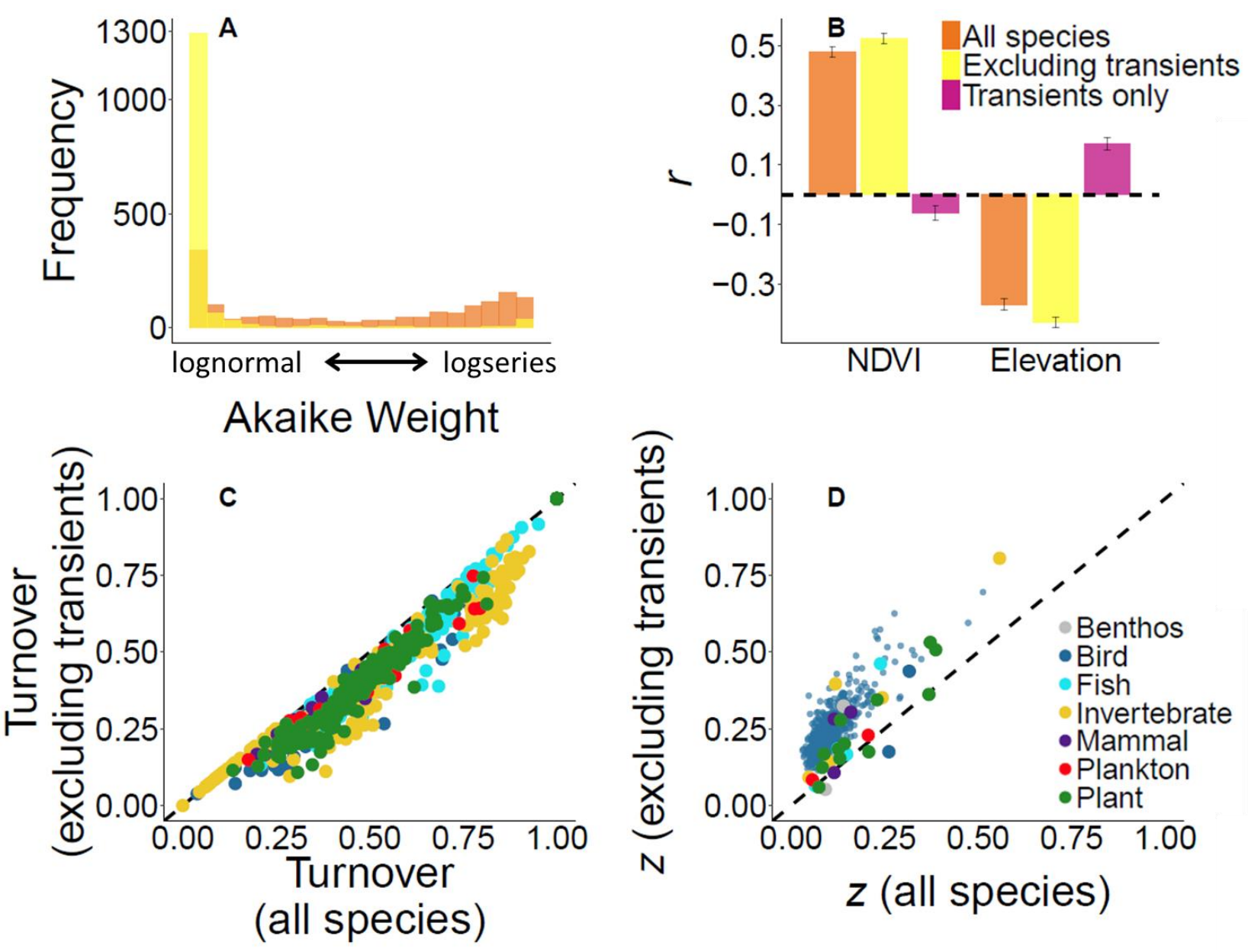

Figure A6. Impact of excluding transient species on four ecological patterns as displayed in Figure 5 in the main text, but where transient species are defined as those with temporal occupancy $\leq$ $25 \%$. 